\title{
Estudos taxonômicos das Xyridaceae no estado do Paraná, Brasil
}

\author{
Taxonomic studies of Xyridaceae of Paraná state, Brazil
}

Eduardo Damasceno Lozano ${ }^{1,4}$, Eric de Camargo Smidt ${ }^{2} \&$ Maria das Graças Lapa Wanderley ${ }^{3}$

\begin{abstract}
Resumo
É apresentado o estudo taxonômico da família Xyridaceae para o estado do Paraná, a qual é representada apenas pelo gênero Xyris, com 22 espécies típicas de ambientes campestres. São referidos três novos registros para o estado: Xyris glandacea, X. metallica e X. uninervis, ampliando a área de distribuição destas para a Região Sul do Brasil. Outras novidades são um novo sinônimo (Xyris simulans var. subtortula sob X. asperula) e o restabelecimento de $X$. dusenii. São apresentados chave de identificação, descrições, comentários, ilustrações e dados sobre a distribuição geográfica das espécies.
\end{abstract}

Palavras-chave: campos sulinos, Poales, taxonomia.

\begin{abstract}
We present the taxonomic treatment of the Xyridaceae family for the state of Paraná. It is represented exclusively by the genus Xyris, with 22 species typical of grasslands. Three new records are reported for the state: Xyris glandacea, $X$. metallica and X. uninervis, all of them extends its distribution area to southern Brazil. Other novelties are a new synonym (Xyris simulans var. subtortula under Xyris asperula) and the reestablishment of Xyris dusenii. An identification key, descriptions, comments, illustrations and data on the geographical distribution of the species are provided.
\end{abstract}

Key words: Southern grasslands, Poales, taxonomy.

\section{Introdução}

Xyridaceae C. Agardh está incluída em Poales e compõe o clado das xirídeas (Xyrids), juntamente com Eriocaulaceae (Bouchenak-Khelladi et al. 2014). A família apresenta distribuição essencialmente pantropical (Kral 1998) e possui cinco gêneros com aproximadamente 430 espécies. Com cerca de 400 espécies, o gênero Xyris Gronov. ex L. é o maior da família, tendo sua amplitude de distribuição coincidente com a das Xyridaceae (Mota et al. 2015; Wanderley 2017). As demais espécies estão incluídas em quatro pequenos gêneros confinados principalmente ao norte da América do Sul: Abolboda (23 spp.), Achlyphila Maguire \& Wurdack (uma sp.), Aratitiyopea Steyerm. \& P.E. Berry (uma sp.), e Orectanthe (duas spp.) (Smith \& Downs 1968; Campbell
2005). A exceção são três espécies de Abolboda que se distribuem até o trópico de capricórnio (Flora do Brasil 2020 em construção). As espécies de Xyris compreendem plantas herbáceas, terrícolas, raramente aquáticas, ocorrendo em terrenos úmidos a pantanosos (Smith \& Downs 1968; Wanderley 2003), sendo o único gênero com registros para o Paraná (Lozano 2014).

O gênero Xyris é caracterizado principalmente por possuir inflorescência em espiga, com flores guarnecidas por brácteas no ápice de um longo pedúnculo, em geral maior que as folhas. As flores são geralmente amarelas e apresentam sépalas modificadas, sendo a anterior membranácea, recobrindo a corola antes da antese e duas laterais naviculares, estas com grande valor taxonômico (Wanderley 2011).

\footnotetext{
${ }^{1}$ Universidade de São Paulo, Inst. Biociências, Depto. Botânica, R. do Matão 277, Cidade Universitária, 05508-090, São Paulo, SP, Brasil.

${ }^{2}$ Universidade Federal do Paraná, Setor de Ciências Biológicas, Centro Politécnico, Jardim das Américas, 81531-980, Curitiba, PR, Brasil.

${ }^{3}$ Instituto de Botânica, Núcleo de Pesquisas Curadoria do Herbário, Av. Miguel Stéfano 3687, 04301-902, São Paulo, SP, Brasil.

${ }^{4}$ Autor para correspondência: eduardo_d111@hotmail.com
} 
No Brasil, o gênero é composto por cerca de 180 espécies (quase $50 \%$ da riqueza da família), das quais $73 \%$ delas são endêmicas, evidenciando a grande representatividade do gênero no país (Wanderley 2010).

As espécies de Xyris ocorrentes no Paraná foram tratadas brevemente por Smith \& Downs (1968) e citadas em levantamentos florísticos, onde muitas vezes foram identificadas erroneamente (Aguiar \& Vieira 2011; Andrade et al. 2011; Cervi et al. 2007; Dalazoana 2010; Hatschbach et al. 2005; Kozera et al. 2009, 2012; von Linsingen et al. 2006; Mocochinski \& Scheer 2008; Ritter et al. 2010; Tramujas 2000). Isto ressalta a importância de trabalhos como este, que além de revisar as coleções dos herbários, apresentam meios para a identificação das espécies.

O presente trabalho teve por objetivo realizar um estudo taxonômico das espécies de Xyridaceae do estado do Paraná, apresentando uma chave analítica, descrições e ilustrações dos táxons, comentários sobre as delimitações taxonômicas das espécies, e observações dos ambientes onde as mesmas ocorrem.

\section{Material e Métodos}

O estado do Paraná situa-se na Região Sul do Brasil (Fig. 7) e possui uma área de ca. 200 mil km², dos quais, segundo Maack (1968), eram originalmente recobertos por ca. $31 \mathrm{mil}$ $\mathrm{km}^{2}$ de campos naturais. Esta fitofisionomia está distribuída em seus três planaltos, assim como no cume das montanhas da Serra do Mar e na restinga (Maack 1968; Roderjan et al. 2002).

Segundo a classificação de Köppen, o estado do Paraná apresenta os tipos climáticos $\mathrm{Cfa}$ (subtropical) com verões quentes e $\mathrm{Cfb}$ (temperado) com verões frescos. A temperatura média é inferior a $18{ }^{\circ} \mathrm{C}$ no mês mais frio e superior a $22{ }^{\circ} \mathrm{C}$ no mais quente (Alvares et al. 2013). As vegetações campestres do estado, com exceção dos que ocorrem nas adjacências de vegetação de restinga, encontram-se em sua maioria acima dos $900 \mathrm{~m}$ de altitude e apresentam predominantemente o clima $\mathrm{Cfb}$.

Os estudos foram baseados em expedições de coleta realizadas entre os anos de 2012 e 2015, através de expedições de coleta realizadas em 26 municípios do estado, onde predominam vegetação de campos naturais. Foram analisadas coleções dos acervos dos seguintes herbários: ALCB, CTES, EFC, FLOR, FUEL, FURB, HB, HBR, HCF, HUCS, HUCP, HUEM, HUPG, ICN, IRAI,
MBM, PACA, PKDC, PEL, R, RB, SP, SPF, UEC e UPCB (acrônimos segundo Thiers, continuamente atualizado).

Foram analisadas 1.739 exsicatas (considerando 848 registros e suas duplicatas) (Apêndice), das quais 348 foram oriundas das expedições de coleta realizadas para este estudo, estando as mesmas depositados nos herbários FLOR, HCF, ICN, MBM, NY, RB, SP e UPCB. Considerando a grande quantidade de amostras analisadas, foi selecionada apenas uma exsicata por município para compor o material examinado selecionado.

Para confecção dos mapas de distribuição das espécies optou-se pela organização por município, para facilitar a comparação entre as áreas de distribuição das espécies, porém comentários sobre as formações vegetais onde as espécies ocorrem foram discutidas nos comentários das espécies.

A identificação das espécies e a obtenção dos dados referentes à sua distribuição geográfica foram baseadas nas informações contidas nas etiquetas de herbário, e em literatura específica (Flora do Brasil 2020 em construção; Kral \& Wanderley 1988; Kunth 1843; Lozano et al. 2016a; Malme 1899, 1908, 1913, 1925; Martius 1841; Miquel 1844; Nilsson 1892; Richard 1792; Seubert 1855; Smith \& Downs 1960, 1965, 1966, 1968; Thunberg 1794; Wanderley 2003, 2011). Adicionalmente foram analisados materiais tipo dos táxons estudados ou fotografias dos mesmos. As imagens analisadas estão disponíveis nos sites dos herbários B, BR, K, L, M, NY, Pe S (acrônimos segundo Thiers, continuamente atualizado).

A descrição do gênero Xyris foi baseada na amplitude da variação morfológica das espécies ocorrentes no estado. As descrições das espécies foram padronizadas com base no software Open DELTA (Dallwitz et al. 2011). As medidas quantitativas e qualitativas seguiram a nomenclatura utilizada por Wanderley (2011). As medidas da largura foram tomadas na região mais larga das estruturas morfológicas.

\section{Resultados e Discussão}

Com base nos estudos realizados, foram reconhecidas para o estado do Paraná 22 espécies de Xyridaceae, todas pertencentes ao gênero Xyris. Destas, três constituem novos registros para o Paraná: Xyris glandacea L.A.Nilsson, $X$. metallica Klotzsch ex Seub. e X. uninervis Malme. Ademais, uma nova espécie foi descrita baseada nos estudos desta flora: X. cervii E.D.Lozano \& 
Wand., ocorrendo nos estados do Paraná, São Paulo e Minas Gerais. Duas espécies são endêmicas do estado do Paraná: Xyris dissitifolia Kral \& Wand. e $X$. piraquarae L.B.Sm. \& Downs. Outras quatro também ocorrem somente nos estados vizinhos: $X$. hatschbachii L.B.Sm \& Downs e $X$. neglecta L.A.Nilsson (PR, SP, SC); X. lucida Malme (PR, SC) e $X$. uninervis Malme (PR, SP) (Flora do Brasil 2020 em construção).

Comparando com o elevado número de espécies de Xyridaceae no Brasil, a relativamente baixa diversidade do estado pode ser explicada em partes por sua localização subtropical, uma vez que o gênero é mais diverso em regiões tropicais. Outro fator que pode influenciar a baixa riqueza no Paraná é a pequena área originalmente ocupada por campos naturais, ca. 15\% (Maack 1968).

Atualmente 27 espécies de Xyris se encontram no livro vermelho da flora do Brasil, das quais seis são registradas para o Paraná: Xyris hatschbachii (CR), X. lucida (EN), X. neglecta (EN), X. rigida Kunth (CR), X. stenophylla L.A.Nilsson (VU) e X. uninervis (CR) (Wanderley et al. 2013). A principal ameaça às Xyridaceae no Paraná é a perda de hábitat, que está intimamente relacionada ao crescimento das áreas de silvicultura de Pinus spp. no estado. Estas espécies são exóticas invasoras de áreas abertas (Ziller \& Galvão 2002), que devido ao sombreamento e acumulo de acículas, não permitem o desenvolvimento de espécies heliófilas (Ziller 2000), como as Xyris. Isto afeta negativamente a riqueza das espécies herbáceas nos locais onde indivídus de Pinus spp. estão presentes (Falleiros et al. 2011).

Durante as fases de campo foi observado que na maioria das espécies, indivíduos que estavam mais próximos à água (poças e riachos), possuíam um porte maior se comparado aos indivíduos que estavam em solo mais seco.

\section{Táxons excluídos e duvidosos}

Xyris reitzii L.B.Sm. \& Downs era citada para o estado do Paraná (Smith \& Downs 1968), porém analisando seu protólogo e seu isótipo depositado no herbário HBR foi constatado que este táxon possivelmente seja um sinônimo de $X$. neglecta. Por este motivo, optou-se pela não inclusão de $X$. reitzii no presente trabalho. Estudos com estas espécies estão em andamento com o intuito de compreender melhor a delimitação dos táxons.

Durante a análise das exsicatas do Paraná foi constatada que as identificações de Xyris filifolia
L.A.Nilsson, $X$. teres L.A.Nilsson e $X$. vacillans Malme estavam baseadas em determinações errôneas de outros táxons, principalmente Xyris neglecta L.A.Nilsson. Deste modo estas espécies foram excluídas da listagem para o estado.

Embora não tenham sido encontradas durante as expedições de coleta e nos herbários analisados, possivelmente as espécies Abolboda pulchella Humb. \& Bonpl. e Xyris brevifolia Mich. ocorram no Paraná. Ambas as espécies possuem registros no estado de São Paulo em locais próximos à divisa com o Paraná, nos municípios de Itararé (M.C.C. Ferreira 108 [UEC]) e Cananéia (M.E. Basso MEB-07 [UEC]) respectivamente.

\section{Tratamento taxonômico}

Xyris Gronov. ex L., Sp. Pl., 1: 42. 1753.

Plantas herbáceas, terrícolas, raramente aquáticas, perenes ou anuais, cespitosas ou solitárias. Rizoma ereto ou horizontal, com entrenós geralmente curtos, recoberto pelas bainhas foliares, em geral, delgado ou robusto, raramente aéreo; raízes fibrosas ou delicadas. Folhas espiraladas a dísticas, equitantes; bainha aberta, pouco a muito distinta da lâmina, alargando em direção à base, margem ciliada a glabra; lígula conspícua, inconspícua ou ausente na região de transição da bainha com a lâmina; lâmina ereta ou torcida, achatada, subcilíndrica, cilíndrica ou filiforme, raro quadrangular, superfície lisa, estriada ou costelada, tuberculada, rugosa ou transverso-rugosa, margem ciliada a glabra. Espata conduplicada. Pedúnculo áfilo, cilíndrico a achatado, muitas vezes com costelas, eventualmente alado, superfície lisa, tuberculada ou rugosa, ciliado a glabro. Inflorescência em espiga, pauciflora a multiflora, ovoide, elipsoide, cilíndrica a globosa, brácteas estéreis poucas a numerosas, côncavas, em geral castanhas, concolores ou com uma mácula na face dorsal verde, cinza ou avermelhada, carenadas ou não, ciliadas a glabras, margem inteira, lacerada ou lacerado-fimbriada, algumas vezes com coloração distinta, brácteas florais semelhantes às estéreis ou raramente distintas destas. Sépalas 3, a anterior cuculada, membranácea, alva, esverdeada, amarelada ou avermelhada, caduca na antese, as duas laterais naviculares, carenadas, livres ou concrescidas, equilaterais a inequilaterais, em geral rígidas; pétalas 3 , amarelas a esbranquiçadas quando velhas, unguiculadas, lobos expandidos; estaminódios 3, epipétalos, bifurcados distalmente, em geral densamente pilosos, raro glabros; estames 3 , epipétalos, anteras basifixas com deiscência 
rimosa, grão de pólen elipsóide e monossulcado; gineceu com estilete trífido, geralmente conado até aproximadamente a metade do comprimento ou mais, apêndices ausentes, estigmas expandidos ou não; ovário súpero, unilocular; placentação basal, suprabasal, central-livre ou parietal. Fruto cápsula septífraga; sementes pequenas, estriadas a reticuladas, geralmente numerosas.
Xyris é caracterizado principalmente por apresentar inflorescências em espigas no ápice de um pedúnculo relativamente longo e flores amarelas. No Paraná ocorre exclusivamente em ambientes campestres, onde compõe a relva graminóide ou agem como espécies pioneiras sobre o solo exposto ou em formação, sobre a matriz rochosa.

\section{Chave de identificação das espécies de Xyris do Paraná}

1. Brácteas com mácula conspícua.

2. Folhas com lígula.

3. Sépalas laterais com carena longo-ciliada (Figs. 1p; 4q; 5c, h).

4. Lâminas quadranguladas (Fig. 5b); pedúnculo multi-costelado

15. Xyris regnellii

4'. Lâminas achatadas a sub-cilíndricas; pedúnculo sem costelas.

5. Brácteas com margem distintamente laceradas (Fig. 4n).......... 13. Xyris neglecta

5'. Brácteas com margem inteira.

6. Sépalas laterais sub-equilaterais, carena lanuginosa no ápice (Fig. 1p).....

4. Xyris dissitifolia

6'. Sépalas laterais inequilaterais, carena longo-ciliada nos $2 / 3$ superiores (Fig. $5 \mathrm{~h})$.

16. Xyris rigida

3'. Sépalas laterais com carena glabra ou apenas curto-ciliada.

7. Estaminódios glabros (Fig. 5o)

17. Xyris savanensis

7'. Estaminódios pilosos.

8. Lâmina cilíndrica a sub-cilíndrica

5. Xyris dusenii

8'. Lâmina achatada.

9. Pedúnculo bialado, bainha em geral amarelada

14. Xyris piraquarae

9'. Pedúnculo 1-costelado; bainha castanho escura a negra

11. Xyris lucida

2'. Folhas sem lígula.

10. Placentação parietal

10. Xyris jupicai

10'. Placentação basal, supra-basal ou central-livre.

11. Sépalas laterais com carena longo-ciliada (Fig. 20)

8. Xyris hatschbachii

11'. Sépalas laterais glabras ou apenas curto-ciliadas.

12. Sépalas laterais com carena curto-ciliada (Fig. 2i); folhas maiores que $10 \mathrm{~cm}$ compr.

7. Xyris guaranitica

12'. Sépalas laterais glabras (Fig. 6k); folhas menores que $5 \mathrm{~cm}$ compr.

20. Xyris tenella

1’. Brácteas sem mácula.

13. Folhas com lígula.

14. Placentação parietal; folhas dísticas; frutos em regra ultrapassando o tamanho da bráctea ...

2. Xyris capensis

14'. Placentação basal a suprabasal; folhas espiraladas; frutos não como acima.

15. Rizoma com entrenós longos (Fig. 6c), bainha castanho clara, opaca; número de brácteas estéreis não superando 4 19. Xyris stenophylla

15'. Rizoma com entrenós curtos; bainha castanho escura, fulgente; número de brácteas estéreis superior a 8 .

22. Xyris uninervis

13'. Folhas sem lígula.

16. Pedúnculo com costelas curto-ciliadas.

17. Brácteas com margem lacerada.

18. Brácteas com margem castanho-avermelhada

18. Xyris schizachne

18'. Brácteas com margem alvo-hialina

9. Xyris hymenachne 
17’. Brácteas com margem inteira.

19. Brácteas amareladas; pedúnculo 2-costelado.

6. Xyris glandacea

19'. Brácteas castanho-escuras; pedúnculo 1-costelado.

12. Xyris metallica

16'. Pedúnculo com costelas glabras ou sem costelas.

20. Lâminas filiformes; bainhas deliquescentes.

3. Xyris cervii

20'. Lâminas achatadas.

21. Brácteas amareladas

20. Xyris tenella

21. Brácteas castanhas.

22. Folhas e pedúnculo rugosos; bráctea com margem inteira

1. Xyris asperula

22'. Folhas e pedúnculo lisos; bráctea com margem hialina.

23. Folhas espiraladas

21. Xyris tortula

23'. Folhas distintamente dísticas

9. Xyris hymenachne

1. Xyris asperula Mart., Flora 24(2): 57. 1841.

Fotos disponíveis em Lozano et al. (2016b).

Xyris simulans var. subtortula Malme (1913: 61).

Síntipos: Brasil. Paraná, Tamanduá, 2.II.1909, $P$

Dusén 7647 (B, S) syn. nov. $\quad$ Figs. 1a-f; 7a

Erva solitária ou cespitosa, perene, base dilatada, bulbiforme, mucilagem hialina presente. Rizoma horizontal com entrenós curtos. Folhas 19,8-41,9 cm compr., espiraladas, torcidas; bainha $12-30,9 \times 1,3-2,3 \mathrm{~cm}$, abruptamente dilatada na base, castanho-escura para a base, transversorugosa, margem hialina para base, tricomas longos na base, ca. 1,5 mm compr.; lâmina 11-13 × 0,04$0,17 \mathrm{~cm}$, achatada, verde a castanha, transversorugosa a escabra, estriada, com pontuações, margem rugosa, ápice acuminado. Lígula ausente. Espata 8,5-17,7 × 0,24-0,44 cm, castanho-clara a castanho-escura na base, carena presente apenas para o ápice, ciliada para a base, lâmina presente. Pedúnculo 46-73 × 0,1-0,16 cm, sub-cilíndrico, verde a castanho, tranverso-rugoso, sem costelas. Espiga 8,4-19,1 × 6-10,8 mm, ovoide; brácteas castanho-escuras, as basais carenadas, mácula ausente, margem inteira, concolor, glabra; brácteas estéreis ca. 4, oblongas; brácteas florais 14-30, ovadas. Flores com sépala anterior membranácea, amarelada; sépalas laterais $6-7,5 \mathrm{~mm}$ compr., inclusas a levemente exsertas, oblanceoladas a elípticas, inequilatarais, ápice obtuso, carena alargada, curto-ciliada, principalmente da porção mediana ao ápice, tricomas castanhos; lobo das pétalas ca. $4 \times 3,5 \mathrm{~mm}$, obovado, margem lisa; estaminódios ca. 1,7-2,7 mm compr., densamente pilosos por todo ramo; estames ca. 2,3 $\mathrm{mm}$ compr., anteras oblongas; estilete $6,4-8,2 \mathrm{~mm}$, ramos 2,5-3 mm compr.; placentação basal. Cápsula ca. 4,1-4,5 $\times 2-2,2 \mathrm{~mm}$, obovoide a fusiforme. Sementes ca. $0,5 \times 0,3 \mathrm{~mm}$, castanho-avermelhadas, translúcidas, globosas, estriadas, ápice apiculado.
Material examinado selecionado: Balsa Nova, Tamanduá, 2.II.1909, fr., P. Dusén 7647 (Síntipos B, S de $X$. simulans var subtortula). Campo Largo, próximo ao portal de São Luís do Purunã, 2528'27'S, 4942'38'O, 4.XII.2013, fl., E.D. Lozano 2168 (MBM, SP). Carambeí, Rio São João, 18.II.2014, fl., E.D. Lozano \& D.P. Saridakis 2637 (MBM, NY, SP, UPCB). Jaguariaíva, Lageado Cinco Reis, 2453'59'S, 507'49”O, 18.I.1965, fl., L.B.Smith 14607 (HBR). Lapa, Rio Passa Dois, 15.II.1967, fl., G. Hatschbach 15982 (MBM). Palmeira, BR-376, entre o Rio das Pombas e Rio dos Papagaios, 2526'29"S, 4944'58"O, 22.II.2013, fl. e fr., E.D. Lozano et al. 1235 (MBM, NY, SP). Piraquara, Rio Iraí, 22.XII.1992, fl., A. Bufrem 34 (MBM). Ponta Grossa, Rio Tibagi, 7.I.1904, fr., P. Dusén 3736 (Síntipos S de $X$. simulans var subtortula); estrada para o Capão da Onça, 256'24"S, 50¹'23'O, 20.XII.2013, fl., E.D. Lozano \& B. Damasceno 2520 (MBM, NY, RB, SP, UPCB). Tibagi, P.E. Guartelá, 24³4'3”S, 50¹5'35'O, 21.XII.2013, fl. e fr., E.D. Lozano \& B. Damasceno 2538 (HCF, MBM, NY, RB, SP, UPCB). Ventania, Faz. Santa Inês, 11.II.2005, fl., D.A. Estevan 603 (FUEL, SP).

Distribuição e hábitat: espécie endêmica do Brasil, típica dos Cerrados da região Central do país (Wanderley 2011), tem no Paraná seu limite austral de distribuição. No Paraná, ocorre apenas na região dos Campos Gerais, crescendo preferencialmente em solos periodicamente drenados como barrancos e declives, geralmente sobre substrato arenoso.

Fenologia: é encontrada com flores de novembro a maio.

Notas taxonômicas: suas principais características são a base bulbiforme com forte brotação lateral, superfície das folhas rugosas e bainha longa, ca. $2 / 3$ da folha, que se fusiona gradativamente com a lâmina. A espécie pode ser confundida com Xyris metallica e Xyris tortula por apresentar lâmina achatada e brácteas concolores. Diferencia-se de $X$. metallica pelos tricomas relativamente longos na base da bainha (ca. $1,5 \mathrm{~mm}$ ) e de $X$. tortula por apresentar superfície foliar transverso-rugosa. 


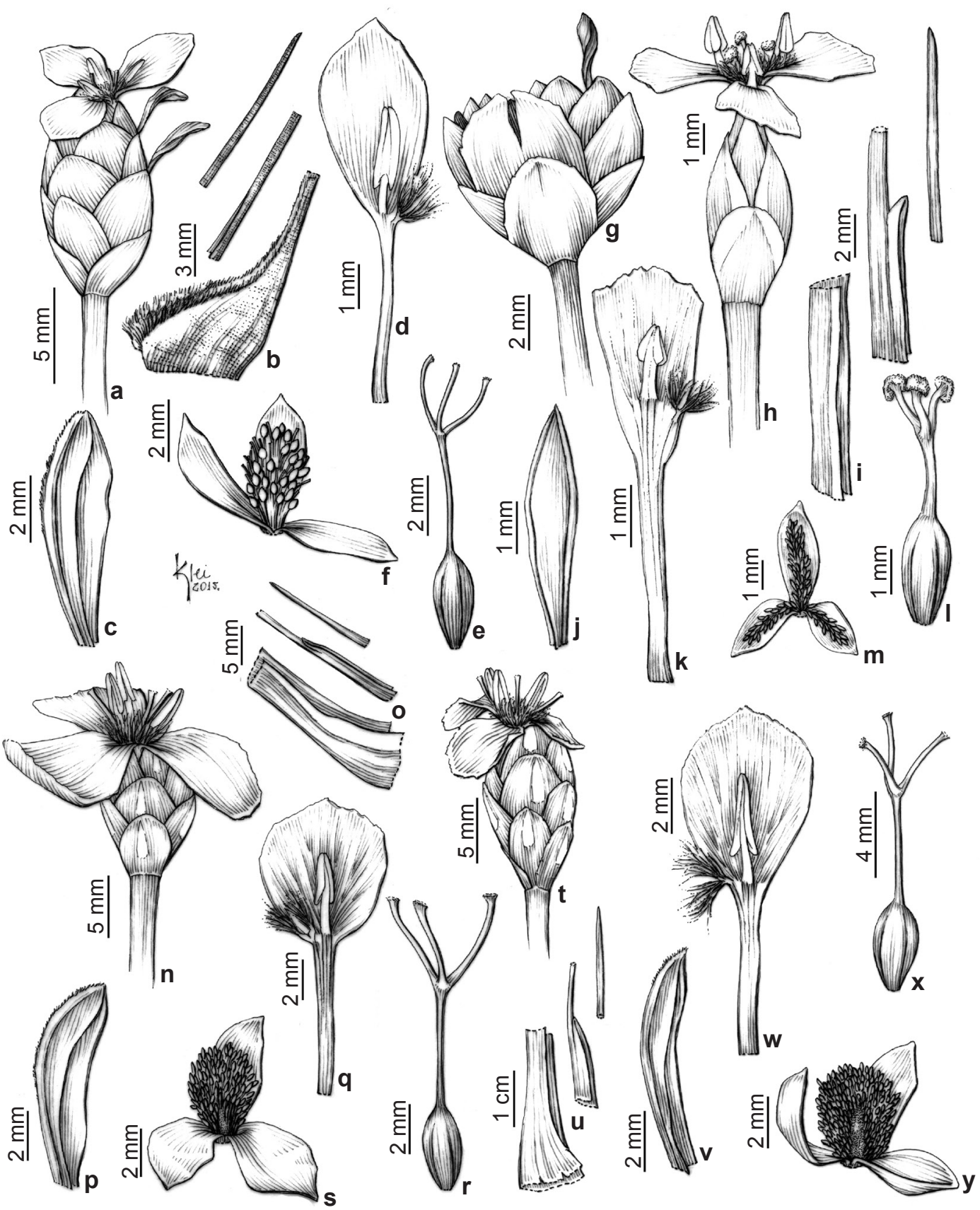

Figura 1 - a-f. Xyris asperula - a. espiga; b. seções da folha; c. sépala lateral; d. pétala com estame e estaminódio; e. gineceu; f. cápsula com placentação basal. g-m. Xyris capensis - g. espiga em fruto; h. espiga em flor; i. seções da folha; j. sépala lateral; k. pétala com estame e estaminódio; l. gineceu; m. cápsula com placentação parietal. n-s. Xyris dissitifolia - n. espiga; o. seções da folha; p. sépala lateral; q. pétala com estame e estaminódio; r. gineceu; s. cápsula com placentação suprabasal. t-y. Xyris dusenii - t. espiga; u. seções da folha; v. sépala lateral; w. pétala com estame e estaminódio; $\mathrm{x}$. gineceu; $\mathrm{y}$. cápsula com placentação central-livre.

Figure 1 - a-f. Xyris asperula - a. spike; b. leaf sections; c. lateral sepal; d. petal with stamen and staminode; e. gynoecium; f. capsule with basal placentation. $\mathrm{g}$-m. Xyris capensis - g. spike with fruit; h. spike with flower; i. leaf sections; j. lateral sepal; k. petal with stamen and staminode; 1. gynoecium; m. capsule with parietal placentation. n-s. Xyris dissitifolia - n. spike; o. leaf sections; p. lateral sepal; q. petal with stamen and staminode; r. gynoecium; s. capsule with suprabasal placentation. t-y. Xyris dusenii - t. spike; u. leaf sections; v. lateral sepal; w. petal with stamen and staminode; $\mathrm{x}$. gynoecium; $\mathrm{y}$. capsule with free-central placentation. 
Xyris simulans var. subtortula foi considerada sinônimo de X. tortula por Smith \& Downs (1965), porém durante a análise do material-tipo desta variedade foi constatado que este táxon é de fato um sinônimo de Xyris asperula. A principal característica diagnóstica citada por Malme (1913) na descrição de $X$. simulans var. subtortula é a superfície da folha transverso-rugosa. Esta característica somada a outras da descrição e observada em seus tipos a enquadra em Xyris asperula.

Um de seus síntipos depositado no Herbário S está identificado como X. asperula por Lyman B. Smith, em 1968 e por Robert Kral, em 1991. Porém a sinonimização não foi publicada até o momento, sendo aqui proposta Xyris simulans var. subtortula como sinônimo de $X$. asperula.

2. Xyris capensis Thunb., Prodr. Pl. Cap.: 12. 1794. Fotos disponíveis em Lozano et al. (2016b).

Figs. 1g-m; $7 b$

Erva em geral solitária ou cespitosa, formando pequenas touceiras, perene, base pouco dilatada, mucilagem hialina presente. Rizoma ereto com entrenós longos ou horizontal com entrenós curtos. Folhas 4,5-19,8 cm compr., dísticas, eretas; bainha $1,7-8,7 \times 0,34-0,81 \mathrm{~cm}$, pouco dilatada na base, castanho-clara a verde, lisa, margem hialina, glabra; lâmina 3-11 ×0,11-0,24 cm, achatada, verde a castanha, lisa, margem glabra, ápice acuminado. Lígula presente. Espata 5,5-11,8 $\times 0,22-0,41 \mathrm{~cm}$, verde, carena glabra, margem hialina, glabra, lâmina presente. Pedúnculo $24,3-48,1 \times 0,05-0,18 \mathrm{~cm}$, sub-cilíndrico, verde a castanho, liso, sem costelas a 2-costelado, costelas glabras. Espiga, 5-6,8 × 3-4,1 mm, elipsoide a levemente obovoide; brácteas castanho-claras a amareladas, carenadas, mácula ausente, margem inteira, concolor, glabra; brácteas estéreis ca. 4, ovadas; brácteas florais ca. 4-8, ovadas. Flores com sépala anterior membranácea, avermelhada; sépalas laterais $3,6-5,7 \mathrm{~mm}$ compr., inclusas, oblanceoladas a elípticas, equilaterais a subequilaterais, ápice obtuso, raro agudo, carena estreita, glabra; lobo das pétalas ca. 3,2 × 1,6 mm, obovado, margem erosa; estaminódios ca. 0,6 $\mathrm{mm}$ compr., densamente pilosos por todo ramo; estames ca. 1,4 $\mathrm{mm}$ compr., anteras oblongas; estilete ca. 3,1 mm compr., ramos ca. 1,2 mm compr.; placentação parietal. Cápsula ca. 3,8-4,3 $\times 1,5 \mathrm{~mm}$, obovoide, sementes ca. $0,5 \times 0,2 \mathrm{~mm}$, castanho-avermelhadas, translúcidas, ovoides, reticuladas, ápice apiculado.
Material examinado selecionado: Balsa Nova, Tamanduá, 6.XI.1966, fl., G. Hatschbach 15062 (HB, MBM, UPCB). Campo Largo, próximo ao portal de São Luís do Purunã, 2528'27'S, 4942'38”O, 4.XII.2013, fl., E.D. Lozano 2171 (MBM, NY, SP, UPCB). Candói, Fazenda Capão Redondo, 2525'24'S, 51 ${ }^{\circ} 48^{\prime} 11^{\prime \prime O}$, 12.XII.2013, fl., E.D. Lozano \& M.E. Engels 2287 (MBM, NY, SP, UPCB). Carambeí, margem do Rio

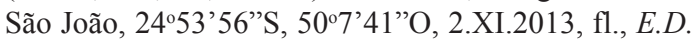
Lozano \& M.E. Engels 1655 (MBM, NY, SP, UPCB). Castro, Catanduvas de Fora, 22.XI.2013, fr., R.S. Moro (HUPG 13438). Curitiba, $50 \mathrm{~km}$ de Curitiba, 7.I.1958, fl, A. Castellanos 21861 (R). General Carneiro, Galinhas, 10.II.1966, fr., G. Hatschbach 13654 (MBM, UPCB). Palmas, refúgio de vida silvestre de Palmas-Fazenda São Pedro, 26'32'34”'S, 51'38'43”O, 13.XII.2013, f1., E.D. Lozano \& M.E. Engels 2347 (FLOR, HCF, MBM, NY, SP, UPCB). Palmeira, BR-376, beira da estrada, próx. rio das Pombas, 2526'34"S, 4944'47'O, 22.II.2013, fl., E.D. Lozano et al. 1238 (MBM, NY, SP, UPCB). Piraquara, margem do reservatório Piraquara II, 2530'38”'S, 49²'0”O, 11.X.2013, fl., E.D. Lozano \& S. Pereira 1535 (HCF, ICN, MBM, NY, RB, SP, UPCB). Ponta Grossa, Rio Lageadinho, 25.IV.2002, fr., R.S. Moro (HUPG 11769). São José dos Pinhais, Cavas próximo Rua da Balsa, 2536'2"S, 49¹5'11'O, 24.IX.2012, fl., E.D. Lozano \& D. Roher 1052 (MBM, SP). Turvo, propriedade da família Rickli, 13.XI.2009, fl. e fr., M.G. Caxambu 2871 (MBM, HCF, FURB).

Distribuição e hábitat: Xyris capensis possui distribuição disjunta entre África, América do Sul e Ásia (Wanderley 2003). No Brasil, ocorre apenas nas Regiões Sul e Sudeste (Flora do Brasil 2020 em construção). No Paraná, ocorre nos campos dos três planaltos, onde geralmente é encontrada na margem de rios lajeados, mas principalmente em áreas com influência antrópica em que há constante fluxo de água, como valas a beira de estradas.

Fenologia: é encontrada com flores de setembro a abril.

Notas taxonômicas: difere das outras espécies de Xyris encontradas no Paraná por apresentar brácteas sem mácula, somada a placentação parietal. As cápsulas são relativamente grandes, geralmente superando o comprimento das brácteas. Apresenta folhas avermelhadas, em geral com a base submersa na água.

O material tipo de Xyris capensis é procedente da África do Sul. Isto leva a hipótese do material do Brasil ser um táxon distinto, pelas variações entre os exemplares destes dois países. Estudos detalhados são necessários para resolver esta questão. 
3. Xyris cervii E.D. Lozano \& Wand., Phytotaxa 245(1): 842016.

Fotos disponíveis em Lozano et al. (2016a,b).

Fig. 7c

Erva solitária ou cespitosa, perene, base dilatada, sub-bulbosa, mucilagem hialina ausente. Rizoma horizontal com entrenós curtos. Folhas 21-50 cm compr., espiraladas, torcidas; bainha $4,1-8,7 \times 0,72-1,21 \mathrm{~cm}$, amplamente dilatada na base, deliquescente, castanho-clara, lisa, margem castanho-hialina a dourada, tricomas castanho-claros na base; lâmina 14,5-41,3 × $0,05-0,1 \mathrm{~cm}$, estreito-achatada a sub-cilíndrica, verde, lisa, margem glabra, ápice acuminado. Lígula ausente. Espata 7,7-19 × 0,15-0,29 cm, castanho-clara, carena ausente, margem hialina, lâmina curta. Pedúnculo 25,5-68 × 0,5-0,07 cm, sub-cilíndrico, verde, glabro. Espiga 6,4-8,6 $\times$ 2,8-4,1 mm, elipsoide, brácteas castanho-claras, carenadas, especialmente na região apical, a basal algumas vezes excurrente, mácula ausente, margem minutamente lacerada, concolor, glabra; brácteas estéreis ca. 5, obovadas; brácteas florais ca. 10, obovadas. Flores com sépala anterior membranácea, avermelhada; sépalas laterais 4,9-6,9 mm compr., inclusas, estreito-lanceoladas, sub-equilaterais, ápice acuminado, carena estreita, glabra a esparsamente curto-ciliada, especialmente na porção mediana; lobo das pétalas ca. 3,8 × 2,6 $\mathrm{mm}$, obovado, margem erosa; estaminódios ca. $2 \mathrm{~mm}$ compr., pilosos por todo ramo; estames ca. 2,5 $\mathrm{mm}$ compr, anteras oblongas; estilete ca. 5,7 mm compr., ramos ca. 2,2 mm compr.; placentação suprabasal. Cápsula ca. 3,6 × 1,5 mm, obovoide. Sementes ca. 0,6 $\times 0,2 \mathrm{~mm}$, castanhoavermelhadas, translúcidas, fusiformes, estriadas, ápice apiculado.

Material examinado selecionado: Jaguariaíva, estrada de ferro Jaguariaíva-Piraí do Sul, 5.V.2006, fl., E. Barbosa 1369 (MBM Parátipo). Ponta Grossa, Capão da Onça, Fazenda Pinheirinhos, 256' $8^{\prime \prime}$ 'S, 50¹'31"O, 11.III.2014, fl. e fr., E.D. Lozano \& D.P. Saridakis 2682 (MBM Holótipo, B, ICN, K, S, NY, RB, SP, UPCB Isótipos); estrada para o Capão da Onça, 25\%6'24"S, 50¹'23”'O, 20.XII.2013, fl., E.D. Lozano \& B. Damasceno 2516 (FLOR, K, MBM, NY, RB, SP, UPCB Parátipos); PARNA dos Campos Gerais - Cachoeira São Jorge, 252'4'S, 50³’20”O, 11.III.2014, fl., E.D. Lozano \& D.P. Saridakis 2642 (HCF, MBM, NY, SP Parátipos). Tibagi, Guartelá, 16.VI.1992, fr., I.J.M. Takeda 508 (HUPG Parátipo).

Distribuição e hábitat: Xyris cervii possui registros nos estados de Minas Gerais, São Paulo e Paraná (Lozano et al. 2016a). Ocorre em campos naturais, preferencialmente sobre solo arenoso com saturação hídrica. Em geral não forma grandes populações. Em campo é encontrada solitária ou formando pequenas touceiras. A espécie destaca-se pela bainha foliar geralmente subterrânea.

Fenologia: é encontrada com flores de dezembro a junho.

Notas taxonômicas: Xyris cervii é caracterizada por apresentar bainha deliquescente com margem lustrosa e com tricomas longos e dourados na região basal. É morfologicamente relacionada à Xyris tortula por apresentarem a base da bainha negra e brácteas com margem lacerada. Diferencia-se desta por apresentar, dentre outras características, sépalas laterais sub-equilaterais e placentação supra-basal.

4. Xyris dissitifolia Kral \& Wand., Ann. Missouri. Bot. Gard. 75: 353. 1988.

Fotos disponíveis em Lozano et al. (2016b).

Figs. 1n-s; 7d

Erva cespitosa, perene, base pouco dilatada, mucilagem hialina ausente. Rizoma ereto com entrenós longos. Folhas 20-55 cm compr., espiraladas, eretas; bainha 13-16 × 0,58-0,65 cm, pouco dilatada na base, castanho-clara, transversorugosa a lisa, margem indistinta, glabra; lâmina $39-45 \times 0,05-0,08 \mathrm{~cm}$, sub-cilíndricas, verde, transverso-rugosa na base a lisa, margem glabra, ápice agudo. Lígula presente. Espata 28-31 × 0,41$0,5 \mathrm{~cm}$, castanho clara, carena ausente, margem glabra, lâmina presente. Pedúnculo 34-59 cm, sub-cilíndrico, verde, liso, sem costelas. Espiga 10,3-11,1 × 11,4-11,9 mm, elipsoide; brácteas castanhas, carena ausente, mácula lanceolada, verde a acinzentada, margem inteira a raro levemente lacerada, concolor, pubescente nas mais jovens; brácteas estéreis ca. 6, ovadas; brácteas florais ca. 8, obovadas. Flores com sépala anterior membranácea, avermelhada; sépalas laterais 8,3-8,7 mm compr., inclusas, oblanceoladas, subequilaterais, ápice obtuso, carena estreita, longociliada, lanuginosa no ápice, tricomas castanhos; lobo das pétalas ca. $6,8 \times 5,4 \mathrm{~mm}$, largo elíptico a oblongo, margem erosa; estaminódios ca. 3,3 mm compr., densamente pilosos por todo ramo; estames ca. 4,5 mm compr., anteras oblongas; estilete ca. $8,6 \mathrm{~mm}$ compr., ramos ca. 4,4 $\mathrm{mm}$ compr.; placentação suprabasal. Cápsula ca. 4,8 $\times 1,6 \mathrm{~mm}$, obovoide. Sementes ca. $1,3 \times 0,4 \mathrm{~mm}$, castanho-avermelhadas, translúcidas, fusiformes, estriadas, ápice apiculado. 
Material examinado selecionado: Campina Grande do Sul, Serra do Capivari Grande, 15.I.1969, fl., G. Hatschbach 20752 (MBM Holótipo); 8.II.1971, G. Hatschbach 26322 (MBM Parátipo); Serra do Ibitiraquire, Abrigo I, 23.I.1970, fl., G. Hatschbach 23404 (MBM Parátipo); Pico Tucum, 14.XI.2003, fl. e fr., A.Y. Mocochinski 233 (MBM).

Distribuição e hábitat: populações de Xyris dissitifolia são conhecidas somente no estado do Paraná e apenas no município de Campina Grande do Sul. Possui registros apenas nos topos de algumas montanhas acima de $1.500 \mathrm{~m}$ de altitude na Serra do Mar, sendo exposta a baixas temperaturas, que podem ser inferiores a $0{ }^{\circ} \mathrm{C}$. Habita organosolo, destacando-se pelo maior porte em meio da vegetação rasteira.

Fenologia: é encontrada com flores de novembro a janeiro.

Notas taxonômicas:émuito similarmorfologicamente a Xyris neglecta, principalmente pelo porte e pelas sépalas laterais sub-equilaterais e lanuginosas no ápice. Diferencia-se desta por geralmente apresentar brácteas com margens inteiras, que são distintamente laceradas em $X$. neglecta. Como já levantado por Wanderley (2003) estas espécies formam um complexo taxonômico, juntamente com Xyris filifolia L.A.Nilsson, $X$. lucida, $X$. rigida, $X$. reitzii, $X$. teres L.A.Nilsson, $X$. vacillans Malme e $X$. wawrae Heimerl. Estudos biossistemáticos são necessários para melhor delimitação destas espécies.

5. Xyris dusenii Malme, Ark. Bot., 19(13): 4. 1925. Fotos disponíveis em Lozano et al. (2016b).

Fig. 1t-y; 7e

Erva cespitosa, perene, base pouco dilatada, mucilagem hialina presente. Rizoma horizontal ou ereto com entrenós curtos. Folhas 73-162 cm compr., espiraladas, eretas; bainha 14-20 × 1,19-1,5 $\mathrm{cm}$, gradativamente dilatada para base, castanhofulgente a avermelhada, lisa, com pontuações alvas, margem hialina, glabra; lâmina 59-100 ×0,12-0,16 $\mathrm{cm}$, cilíndrica a sub-cilíndrica, verde, avermelhada na base, lisa, margem glabra, ápice acuminado. Lígula presente. Espata $21-25 \times 0,54-0,64 \mathrm{~cm}$, avermelhada na base, carena glabra, margem glabra, lâmina presente. Pedúnculo 88-198 × 0,12-0,2 cm, cilíndrico, verde, liso, sem costelas a 1-costelado, costelas quando presentes glabras. Espiga 12,4-13,4 $\times 7,5-9,5 \mathrm{~mm}$, elipsoide a obovoide; brácteas castanho-escuras, carena ausente, mácula ovada a lanceolada, verde, margem inteira, concolor, glabra; brácteas estéreis ca. 10, ovadas; brácteas florais ca. 20, obovadas. Flores com sépala anterior membranácea, avermelhada; sépalas laterais 7-7,5 $\mathrm{mm}$ compr., inclusas, estreito-oblanceoladas, sub-equilaterais, ápice obtuso, carena alargada, esparsamente curto-ciliada, principalmente da porção mediana ao ápice, tricomas avermelhados próximo ao ápice; lobo das pétalas 6,3-6,5 × 2,9-5 mm, obovado, margem erosa; estaminódios 2,5-3,1 $\mathrm{mm}$ compr., densamente pilosos por todo ramo; estames 3,3-3,6 mm compr., anteras oblongas; estilete 9,2-9,6 mm compr., ramos 2,5-3,3 mm compr.; placentação central-livre. Cápsula ca. 4,8 $\times 1,7 \mathrm{~mm}$, obovoide. Sementes ca. $1 \times 0,3$ $\mathrm{mm}$, castanho-avermelhadas, opacas, fusiformes, estriadas, ápice apiculado.

Material examinado selecionado: Bocaiuva do Sul, Campina dos Tavares, 11.XI.1959, fl., G. Hatschbach 6469 (MBM). Curitiba, Parque Barigui, 18.XII.1996, fl., V.A.O. Dittrich 239 (CTES, MBM, UPCB); Morretes, Pilão de Pedra, 27.II.1965, fl., G. Hatschbach 12412 (MBM, UPCB, VIC). Palmas, Santo Agostinho, 6.XII.1971, fl., G. Hatschbach 28304 (MBM, UPCB). Paula Freitas, Varzea do Rio Vagem Grande, 26 ${ }^{\circ}$ '56'S, 5051'27'’, 14.XII.2013, fl. e fr., E.D. Lozano \& M.E. Engels 2356 (ICN, MBM, NY, SP, RB, UPCB). Piraquara, próx. ao reservatório Piraquara II, $25^{\circ} 30^{\prime} 58^{\prime \prime} \mathrm{S}, 49^{\circ} 0^{\prime} 50^{\prime} \mathrm{O}$, 30.X.2013, fl., E.D. Lozano 1610 (MBM, NY, SP). Quatro Barras, estrada da Graciosa-Rio Taquari, 2518'40"S, 4856'1"'O, 20.XI.2013, fl., E.D. Lozano \& M.G.L. Wanderley 2917 (MBM). São José dos Pinhais, $30 \mathrm{~km}$ a leste de Curitiba, 11.I.1949, fl., G. Tesmann 3743 (PKDC). Tijucas do Sul, Rincão, 21.X.1977, fl., G. Hatschbach 40463 (MBM).

Distribuição e hábitat: Xyris dusenii é endêmica do Brasil e possui registros nos estados do Paraná, Santa Catarina e São Paulo. No Paraná é encontrada nos campos na região de Curitiba e acompanhando a bacia do Rio Iguaçu. Ocorre preferencialmente em planícies alagáveis, fazendo parte da vegetação de várzea. É a espécie de Xyris de maior porte registrada no Paraná, com seu pedúnculo chegando a cerca de dois metros de altura.

Fenologia: pode ser encontrada com flores de outubro a fevereiro.

Notas taxonômicas: Xyris dusenii foi sinonimizada em X. neglecta por Smith \& Downs (1965). Porém, durante a análise da descrição e dos materiais tipo dessas duas espécies, verificou-se que $X$. dusenii se trata de uma entidade distinta, sendo aqui reestabelecida. Enquanto $X$. neglecta possui lâmina sub-cilíndrica, brácteas com margem lacerada e pubescente e, sépalas laterais com carena lanuginosa no ápice, $X$. dusenii possui lâmina cilíndrica, brácteas com margem inteira e glabra, e sépalas laterais com carena esparsamente curto-ciliada. 
Xyris dusenii também faz parte do mesmo complexo taxonômico indicado nas notas taxonômicas de $X$. dissitifolia. É muito similar morfologicamente a Xyris teres, por ambas possuírem lâminas cilíndricas e sépalas laterais estreito-oblanceoladas com carena esparsamente curto-ciliada. Difere desta principalmente por $X$. dusenii apresentar bainha lustrosa, enquanto em $X$. teres a bainha é nitidamente opaca.

6. Xyris glandacea L.A.Nilsson, Kongl. Svenska Vetensk.-Akad. Handl. 24(14): 50. 1892.

Fotos disponíveis em Lozano et al. (2016b).

Figs. 2a-f; $7 \mathrm{f}$

Erva solitária ou cespitosa formando pequenas touceiras, perene, base dilatada, mucilagem hialina ausente. Rizoma horizontal com entrenós curtos. Folhas 22,1-29,6 cm compr., espiraladas, eretas, fortemente torcidas; bainha 7,5-10,9 × 0,78-1,01 $\mathrm{cm}$, abruptamente dilatada na base, castanho-clara a castanho-escura, base avermelhada, transversorugosa, margem hialina, ciliada, com tricomas longos na base, $0,9-1,5 \mathrm{~cm}$ compr., carena curtociliada da porção mediana para o ápice; lâmina $15-18,8 \times 0,22-0,36 \mathrm{~cm}$, achatada, castanha, transverso-rugosa, com pontuações vermelhas, margem curto-ciliada, tricomas alvos, ápice acuminado. Lígula ausente. Espata 14,7-15,1 × $0,42-0,59 \mathrm{~cm}$, castanho clara a castanho escura, carena curto-ciliada, margem ciliada, tricomas alvos, lâmina presente. Pedúnculo 42,5-76,3 × 0,17-0,21 cm, sub-cilíndrico, verde a castanho, tranverso-rugoso, 2-costelado, costelas curtociliadas, tricomas alvos. Espiga 9,9-17,9 × 6,5-8,1 $\mathrm{mm}$, elipsoide a ovoide; brácteas amareladas, carena ausente, mácula ausente, margem lacerada, castanho-fulgente, glabra; brácteas estéreis ca. 8 , ovadas; brácteas florais ca. 22, oblongas. Flores com sépala anterior membranácea, amarelada; sépalas laterais 4,9-5,2 $\mathrm{mm}$ compr., inclusas, oblanceoladas a elípticas, fortemente inequilaterais, ápice obtuso, carena alargada para o ápice, ciliadofimbriada, tricomas alvos; lobo das pétalas ca. $2,6 \times 1,8 \mathrm{~mm}$, obovado a elíptico, margem lisa; estaminódios ca. $1 \mathrm{~mm}$ compr., pilosos apenas no ápice do ramo; estames ca. 1,3 mm compr., anteras sagitadas; estilete ca. 3,2 mm compr., ramos ca. 1,3 mm compr.; placentação basal. Cápsula ca. $3 \times 1,6$ $\mathrm{mm}$, globosa. Sementes ca. $8 \times 0,3 \mathrm{~mm}$, castanhoavermelhadas, translúcidas, fusiformes, estriadas, ápice obtuso.

Material examinado selecionado: Ponta Grossa, PARNA dos Campos Gerais - Cachoeira São Jorge,
252'4”'S, 50³'20”'O, 20.XII.2013, fr., E.D. Lozano \& B. Damasceno 2502 (MBM, SP). Carambeí, Rio São João, 2453'59'S, 507'49”O, 18.II.2014, fl. e fr., E.D. Lozano \& D.P. Saridakis 2634 (FLOR, HCF, ICN, MBM, NY, RB, SP, UPCB). Piraí do Sul, Pousada Serra do Pirahy, 27.I.2014, fl., D.P. Saridakis 303 (MBM).

Distribuição e hábitat: Xyris glandacea era registrada anteriormente apenas nos estados da Bahia, Espirito Santo, Minas Gerais, Rio de Janeiro e São Paulo (Wanderley 2011), sendo registrada pela primeira vez para o Paraná durante o desenvolvimento do presente levantamento. No Paraná possui registros apenas na região dos Campos Gerais, onde ocorre exclusivamente em barrancos constantemente úmidos, geralmente próximos a afloramentos rochosos.

Fenologia: é encontrada com flores de dezembro a maio. Foi observada com flores abertas apenas pela manhã.

Notas taxonômicas: Xyris glandacea possuía uma circunscrição contraditória, sendo frequentemente identificada como Xyris ciliata Thunb. nas coleções de herbário (Wanderley 2011). A descoberta desta espécie no Paraná amplia sua distribuição e contribui para o incremento das coleções de herbário deste táxon.

Dentre as espécies que ocorrem no Paraná, pode ser confundida com X. metallica, por ambas apresentarem a margem da lâmina foliar curtociliada e brácteas sem mácula. Mas algumas características de $X$. glandacea como a margem das brácteas castanho-fulgente, sépalas laterais fortemente inequilaterais com a carena ciliadofimbriada, gineceu mais curto que o androceu, estaminódios com tricomas apenas na região apical dos ramos e brácteas amareladas tornam esta espécie distinta.

7. Xyris guaranitica Malme, Bull. Herb. Boissier 7: 77. 1899.

Fotos disponíveis em Lozano et al. (2016b).

Figs. 2g-1; $7 \mathrm{~g}$

Erva cespitosa, perene, base pouco dilatada, mucilagem hialina ausente. Rizoma horizontal com entrenós curtos. Folhas 11,6-29,9 cm compr., espiraladas, dísticas, ereta a torcida; bainha 3-7,11 $\times 0,81-1,65 \mathrm{~cm}$, dilatada na base, castanhofulgente, base avermelhada, lisa, margem hialina, glabra; lâmina 7,6-22,6 × 0,07-0,16 cm, achatada, verde, lisa, margem glabra, ápice acuminado. Lígula ausente. Espata 4,53-10,9 × 0,19-0,42 $\mathrm{cm}$, castanho clara, avermelhada na base, carena 


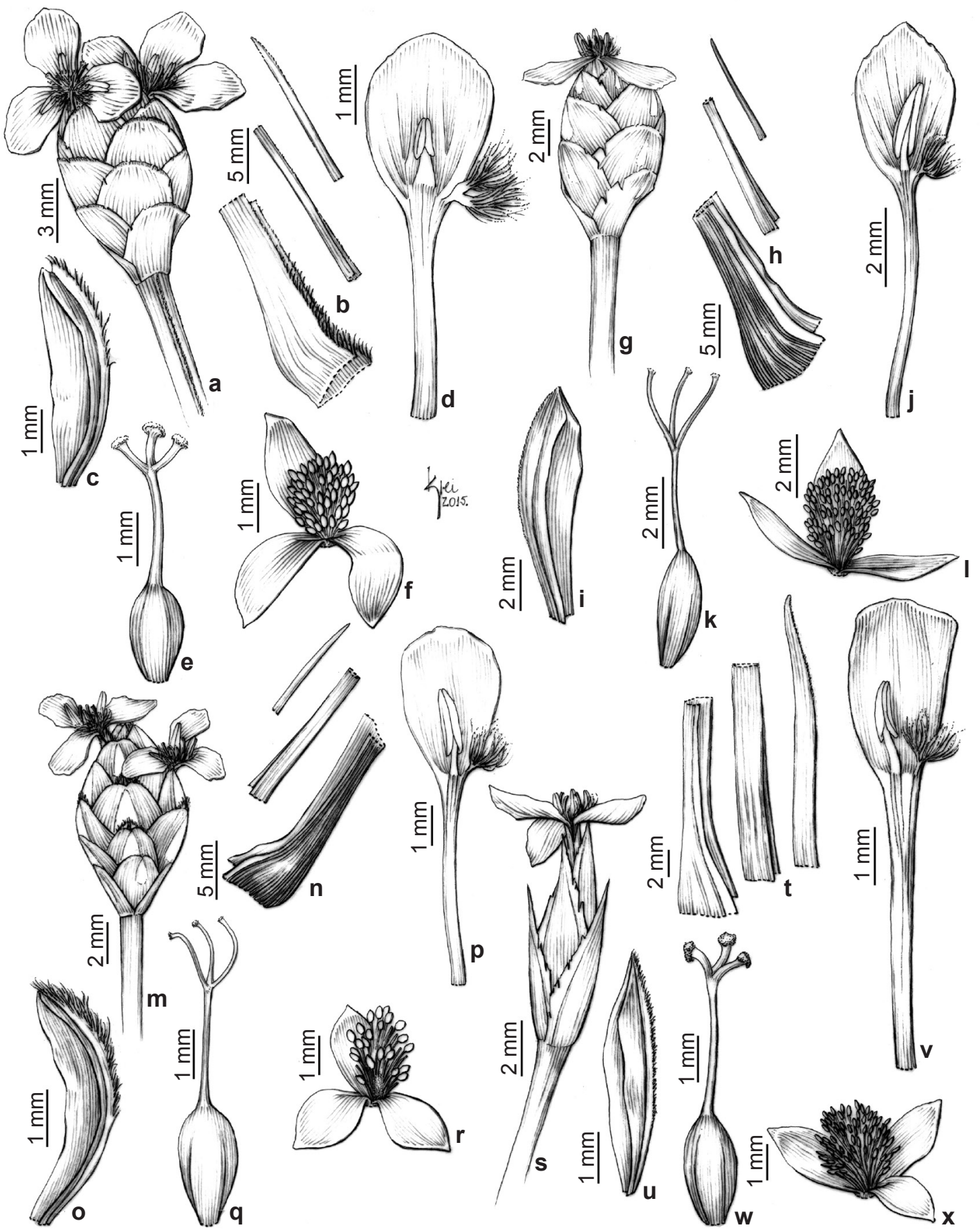

Figura 2 - a-f. Xyris glandacea - a. espiga; b. seções da folha; c. sépala lateral; d. pétala com estame e estaminódio; e. gineceu; f. cápsula com placentação basal. g-l. Xyris guaranitica - g. espiga; h. seções da folha; i. sépala lateral; j. pétala com estame e estaminódio; $\mathrm{k}$. gineceu; 1 . cápsula com placentação basal. m-r. Xyris hatschbachii - m. espiga; $n$. seções da folha; 0 . sépala lateral; p. pétala com estame e estaminódio; q. gineceu; r. cápsula com placentação central-livre. s-x. Xyris hymenachne -s. espiga; t seções da folha; u. sépala lateral; v. pétala com estame e estaminódio; w. gineceu; x. cápsula com placentação basal.

Figure 2 - a-f. Xyris glandacea - a. spike; b. leaf sections; c. lateral sepal; d. petal with stamen and staminode; e. gynoecium; f. capsule with basal placentation. g-l. Xyris guaranitica $-\mathrm{g}$. spike; $\mathrm{h}$. leaf sections; i. lateral sepal; j. petal with stamen and staminode; k. gynoecium; 1 . capsule with basal placentation. m-r. Xyris hatschbachii - m. spike; n. leaf sections; o. lateral sepal; p. petal with stamen and staminode; q. gynoecium; r. capsule with free-central placentation. s-x. Xyris hymenachne - s. spike; t. leaf sections; u. lateral sepal; v. petal with stamen and staminode; w. gynoecium; x. capsule with basal placentation. 
presente apenas no ápice, margem hialina, lâmina presente. Pedúnculo 33,1-60,3 ×0,08-0,14 cm, sub-cilíndrico, torcido, verde, liso, sem costelas. Espiga 7,5-12,1 × 4,7-7,1 mm, elipsoide a ovoide; brácteas castanho-escuras, as basais carenadas, mácula estreito-lanceolada, verde, margem lacerada, concolor, glabra; brácteas estéreis ca. 8 , ovadas; brácteas florais ca. 16, ovadas. Flores com sépala anterior membranácea, castanha; sépalas laterais 5-6,1 mm compr., inclusas, oblanceoladas a estreito-oblanceoladas, inequilatarais, ápice obtuso, carena estreita, curto-ciliada, tricomas castanhos; lobo das pétalas ca. 4,2 × 3,1 mm, obovado a elíptico, margem erosa; estaminódios ca. 2,6 mm compr., densamente pilosos por todo ramo; estames ca. 2,8 mm compr., anteras oblongas; estilete 5,1 mm compr., ramos 1,9 mm compr.; placentação basal. Cápsula ca. 4,4 × 1,4 $\mathrm{mm}$, estreito-elipsoide. Sementes ca. $0,4 \times 0,2$ $\mathrm{mm}$, castanho-claras, translúcidas, obovoides, reticuladas, ápice apiculado.

Material examinado selecionado: Guaraqueçaba, Ilha de Superagui, praia deserta, próximo à casa das Casuarinas, 2520'1'S, 48 7'30'O, 9.I.2014, fl, E.D. Lozano et al. 2546 (HCF, MBM, NY, RB, SP, UPCB). Pontal do Paraná, balneário Shangri-lá, 2537'59'S, 48²5'33"O, 6.I.2014, fl, E.D. Lozano et al. 2541 (FLOR, HCF, ICN, MBM, NY, RB, SP, UPCB). Sengés, S. Antônio, $5 \mathrm{~km}$ ao norte, 28.II.1978, fl, G. Hatschbach 29263 (MBM). Telêmaco Borba, Parque Samuel Klabin, 13.VI.1989, fr, W. Zangano (FUEL 6854).

Distribuição e hábitat: ocorre na Argentina, Paraguai e Brasil, onde está registrada para as regiões Sul, Sudeste e Centro-oeste (Smith \& Downs 1968). Sua distribuição acompanha o litoral do Brasil e a bacia do Rio Paraná. Na Região Sul, é uma espécie típica da restinga herbácea, ocorrendo preferencialmente na vegetação de entre-dunas, a cerca de $150 \mathrm{~m}$ do nível do mar, ou próximo a cursos d'água. No Paraná, as populações sofrem com a influência antrópica direta, pois suas populações no litoral são afetadas pela pressão imobiliária e turismo.

Fenologia: é encontrada com flores de fevereiro a abril.

Notas taxonômicas: pode ser confundida com Xyris hatschbachii, por ambas apresentarem a base das bainhas negras, brácteas com mácula conspícua e porte similar. Entretanto, X. guaranitica apresenta as sépalas laterais inclusas com a carena curtociliada e placentação basal, enquanto em $X$. hatschbachii possui sépalas laterais exsertas com a carena densamente ferrugíneo-pilosa e placentação central-livre.
8. Xyris hatschbachii L.B.Sm. \& Downs, Proc. Biol. Soc. Washington, 73: 248. 1960.

Fotos disponíveis em Lozano et al. (2016b).

Figs. 2m-r; 7h

Erva solitária ou cespitosa formando pequenas touceiras, perene, base dilatada, bulbiforme, mucilagem hialina ausente. Rizoma horizontal com entrenós curtos. Folhas 7-25,2 cm compr., espiraladas, eretas, torcidas; bainha 2,2-7,9 × 0,43-1,55 cm, abruptamente dilatada na base, castanho-escura, principalmente para base, transverso-rugosa, margem hialina, glabra; lâmina 4,7-19,9 × 0,06-0,13 cm, achatada, verde a castanha, transverso-rugosa a lisa, estriada, margem rugosa, glabra, ápice acuminado. Lígula ausente. Espata 5,3-13,2 × 0,2-0,34 cm, verde, castanho escura na base, carena rugosa, margem hialina, lâmina presente. Pedúnculo 17-45,2 × 0,08-0,11 cm, sub-cilíndrico, verde a castanho, tranverso-rugoso ou liso, 1-2-costelado, costelas rugosas. Espiga 6,7-13,1 × 5,3-7,3 mm, elipsoide a obovoide; brácteas castanhas, carena ausente, mácula ovada a lanceolada, verde, margem geralmente inteira, glabra; brácteas estéreis ca. 8, ovadas; brácteas florais ca. 14-26, ovadas. Flores com sépala anterior membranácea, castanha; sépalas laterais 3,9-5,2 mm compr., geralmente exertas, oblanceoladas a lanceoladas, inequilatarais a fortemente inequilaterais, ápice acuminado a obtuso, carena estreita, densamente longo-ciliada, principalmente da porção mediana ao ápice, tricomas avermelhados; lobo das pétalas ca. 3,9 $\times 1,9 \mathrm{~mm}$, obovado a orbicular, margem lisa; estaminódios ca. 1,2 mm compr., densamente pilosos por todo ramo; estames ca. $2 \mathrm{~mm}$ compr., anteras oblongas; estilete 3,7-4,9 mm compr., ramos 1,4-2,3 mm compr.; placentação centrallivre. Cápsula ca. 2,6-2,9 × 1,8-2,3 mm, obovoide. Sementes ca. $0,5 \times 0,3 \mathrm{~mm}$, castanho-claras, translúcidas, elipsoides a fusiformes, estriadas, ápice apiculado.

Material examinado selecionado: Balsa Nova, próximo à Pousada Cainã, 2526'19'S, 4943'28'O, 4.XII.2013, fl., E.D. Lozano 2151 (MBM, NY, SP). Campo Largo, Serra de São Luís do Purunã, 6.I.1948, fl. e fr., G. Hatschbach 828 (PACA Holótipo, MBM Isótipo) Jaguariaíva, Parque Estadual do Cerrado, 249'50"S, 49³9'53"O, 29.XI.2013, fl. e fr., E.D. Lozano \& D.P. Saridakis 2062 (HCF, MBM, NY, SP, UPCB). Lapa, arredores do Parque Estadual do Monge, 2546'21'S, 4942'1' O, 14.XII.2013, fl., E.D. Lozano \& M.E. Engels 2357 (HCF, MBM, NY, RB, SP, UPCB). Palmeira, Recanto dos Papagaios, 25'27'57'S, 4946'5"O, 10.XII.2013, fl., E.D. Lozano \& M.E. Engels 2198 (HCF, 
MBM, NY, RB, SP). Piraí do Sul, entorno da Pousada Pirahy da Serra, 2428'1"S, 50¹'13"O, 27.XI.2013, fl., E.D. Lozano \& D.P. Saridakis 1969 (MBM). Ponta Grossa, Parque Estadual de Vila Velha, 2514'51"S, 4959'30'O, 18.XII.2013, fl., E.D. Lozano 2447 (HCF, ICN, MBM, NY, SP, UPCB). Tibagi, Parque Estadual do Guartelá, 24³4’3”S, 50¹5’35”O, 21.XII.2013, fl. e fr., E.D. Lozano \& B. Damasceno 2537 (MBM, NY, SP, UPCB).

Distribuição e hábitat: é uma espécie endêmica do Brasil, e possui registros apenas para os estados de Paraná, Santa Catarina e São Paulo (Flora do Brasil 2020 em construção). No Paraná é encontrada em toda região dos Campos Gerais, desde a divisa com São Paulo no município de Sengés até Lapa, na divisa com Santa Catarina. Nestes outros estados $X$. hatschbachii possui registros apenas nos campos próximos a divisa com o Paraná.

Ocorre preferencialmente em afloramentos rochosos em locais com substrato arenoso não consolidado, onde que há um constante fluxo de água, sendo raro encontrá-la em outro tipo de ambiente.

Fenologia: é encontrada com flores de outubro a janeiro.

Notas taxonômicas: até o presente estudo, esta espécie possuía apenas três registros, incluindo seus materiais tipo. Durante a análise das coleções de $X$. sororia Kunth para o Paraná e São Paulo e sua obra príncipes, constatou-se que todas as exsicatas determinadas com este táxon se enquadravam em $X$. hatschbachii, porém, a delimitação dessas espécies ainda permanece incerta.

Estudos em andamento com essas duas espécies indicam que $X$. hatschbachii possivelmente seja um sinônimo de $X$. sororia. Como o material tipo de $X$. sororia não possui uma localidade de coleta especifica, indicado como "Brasilia meridionalis", e o tipo de X. hatschbachii foi coletado no Paraná, optamos por manter apenas este táxon nesta flora.

Dentre as espécies ocorrentes no estado, pode ser confundida apenas com $X$. guaranitica, por características já citadas nas notas taxonômicas da espécie.

9. Xyris hymenachne Mart., Flora, 24(2): 55, 1841. Fotos disponíveis em Lozano et al. (2016b).

Figs. 2s-x; $7 \mathrm{i}$

Erva solitária ou cespitosa formando pequenas touceiras, perene, base pouco dilatada, mucilagem hialina ausente. Rizoma horizontal com entrenós curtos. Folhas 4-15 cm compr., dísticas, eretas; bainha $1,9-7,5 \times 0,38-0,99 \mathrm{~cm}$, abruptamente dilatada na base, verde, lisa, margem hialina, carena curto-ciliada, tricomas caducos; lâmina 2,1-7,5 × 0,16-0,42 cm, achatada, verde a vermelha, lisa, margem glabra ou curto-ciliada, principalmente nas folhas jovens, ápice acuminado. Lígula ausente. Espata 3,8-12,5 × 0,18-0,39 cm, verde, carena glabra a curto-ciliada, margem hialina, lâmina presente. Pedúnculo 14-40 × 0,04-0,12 cm, subcilíndrico, verde, liso, com pontuações, 1-costelado, costelas glabras a curto-ciliadas, tricomas alvos. Espiga 7,3-9,3 × 3,3-5,9 mm, elipsoide a obovoide; brácteas castanho-claras, as basais carenadas, mácula ausente, margem lacerada, alvo-hialina, glabra; brácteas estéreis ca. 4, ovadas; brácteas florais ca. 8, obovadas. Flores com sépala anterior membranácea, amarelada; sépalas laterais 4,1-6,2 mm compr., inclusas, estreito-oblongas a estreitooblanceoladas, inequilatarais, ápice acuminado, carena estreita, esparsamente curto-ciliada, mais densos na porção central, tricomas alvos; lobo das pétalas ca. $3 \times 1,6 \mathrm{~mm}$, oblongo a obovado, margem erosa; estaminódios ca. 0,9 mm compr., pilosos por todo ramo; estames ca. $1,1 \mathrm{~mm}$ compr., anteras oblongas; estilete ca. 4,6 mm compr., ramos ca. 1,5 mm compr.; placentação basal. Cápsula ca. $3,6 \times 2 \mathrm{~mm}$, obovoide. Sementes ca. $0,5 \times 0,2 \mathrm{~mm}$, castanho-avermelhadas, translúcidas, elipsoides, reticuladas, ápice apiculado.

Material examinado selecionado: Balsa Nova, Fazenda Tamanduá, 25³2'19'’S, 4942'53'O, 4.XII.2013, fl., E.D. Lozano 2139 (MBM, NY, SP, UPCB). Campo Largo, próximo ao portal de São Luís do Purunã, 25'28'27'S, 4942'38'O, 4.XII.2013, fl., E.D. Lozano 2167 (MBM, UPCB). Carambeí, Rio São João, 2453'59'S, 507'49”'O, 16.II.2014, fl., E.D. Lozano \& D.P. Saridakis 2638 (MBM, NY, SP, UPCB). Curitiba, $50 \mathrm{~km}$ de Curitiba, 7.I.1958, fl, A. Castellanos 21858 (R). Guaratuba, Morro dos Perdidos, 25'53'23"S, 48'57'23”O, 12.II.2014, fl., E.D. Lozano et al. 2621 (MBM, NY, SP, UPCB). Jaguariaíva, estrada para o Parque Estadual do Cerrado, 2412'26"S, 4941'1'O, 1.XII.2013, fl., E.D. Lozano 2126 (MBM, SP, UPCB). Lapa, arredores do Parque Estadual do Monge, 2546'21'S, 4942'1'O, 14.XII.2013, fr., E.D. Lozano \& M.E. Engels 2359 (MBM). Palmeira, BR-376, km 543, rio lajeado à beira da estrada, $25^{\circ} 22^{\prime} 28^{\prime}$ 'S, 49 48'40"O, 17.XII.2013, fr., E.D. Lozano 2386 (MBM, NY, SP, UPCB). Piraí do Sul, Chácara Santa Rita da Serra, 24²7'59'S, 50¹'42”O, 26.XI.2013, fl., E.D. Lozano \& D.P. Saridakis 1887 (MBM, NY, SP, UPCB). Ponta Grossa, PARNA dos Campos Gerais, Cachoeira São Jorge, 25'2'4”S, 50³'20"O, 20.XII.2013, fl., E.D. Lozano \& B. Damasceno 2504 (MBM, SP, UPCB). Sengés, PR-151, Rio Funil, 247'20”S, 49²3'28'O, 30.XI.2013, fl., E.D. Lozano \& D.P. Saridakis 2101 
(FLOR, HCF, MBM, NY, RB, SP, UPCB). Tibagi, P.E. Guartelá, 4.XII.2003, fl., M.R.B. Carmo 474 (HUPG).

Distribuição e hábitat: Xyris hymenachne é restrita à América do Sul, ocorrendo da Venezuela ao Paraguai (Wanderley 2011). No Brasil, ocorre em todas as regiões, tendo no estado de Santa Catarina seu limite austral (Flora do Brasil 2020 em construção). Apresentava poucos registros para o Paraná, porém durante as expedições realizadas no presente trabalho foi observado que a espécie se distribui por toda região dos Campos Gerais, possuindo apenas um registro para a Serra do Mar.

Ocorre preferencialmente em barrancos onde há constante fluxo de água e margens de rios lajeados onde o solo é exposto. Também pode ser encontrada em meio ao campo e locais onde há uma maior competição por espaço, porém com menor frequência.

Fenologia: é encontrada com flores de novembro a abril. Foi observada com flores abertas apenas pela manhã.

Notas taxonômicas: difere das outras espécies ocorrentes no Paraná por apresentar a margem das brácteas longas e hialinas, geralmente laceradas. Pela disposição dística das folhas pode ser vegetativamente confundida com Xyris jupicai ou Xyris savanensis, mas difere destas espécies principalmente por não apresentar mácula nas brácteas.

10. Xyris jupicai Rich., Actes Soc. Hist. Nat. Paris, 1: $106,1792$.

Fotos disponíveis em Lozano et al. (2016b).

Figs. 3a-h; $7 \mathrm{j}$

Erva solitária ou cespitosa, formando pequenas touceiras, anual, base pouco dilatada, mucilagem hialina presente. Rizoma horizontal com entrenós curtos. Folhas 5-60 cm compr., dísticas, eretas; bainha 8-40 × 0,3-3,2 cm, gradativamente dilatada para base, verde com base vermelha a negra, lisa, margem hialina, glabra; lâmina 3,3-20 × 0,18-1,34 cm, achatada, verde, com pontuações lineares vermelhas, lisa, margem levemente espessada, glabra, ápice obtuso. Lígula ausente. Espata 3-21 × 0,17-0,88 cm, castanhofulgente a verde, carena glabra, margem glabra, lâmina presente. Pedúnculo 11-86 × 0,07-0,25 cm, sub-cilíndrico, verde, glabro, 1-2 costelado(s), costelas glabras. Espiga 11-27,3 × 3,7-10,6 mm, elipsoide a ovoide; brácteas castanhas, carena ausente, mácula ovada, verde, margem inteira, concolor, glabra; brácteas estéreis ca. 10, ovadas; brácteas florais 26-42, obovadas. Flores com sépala anterior membranácea, avermelhada; sépalas laterais 4,3-5,3 mm compr., inclusas, elípticas, oblanceoladas ou lanceoladas, equilaterais, ápice agudo, carena estreita, curto-ciliada, tricomas castanhos; lobo das pétalas 3,1-5,3 × 2-2,3 mm, obovado, margem erosa; estaminódios 1,2-1,3 mm compr., pilosos por todo ramo; estames 1,4-1,8 mm compr., anteras oblongas; estilete 3,8-6,1 mm compr., ramos 1,5-1,7 mm compr.; placentação parietal. Cápsula 4,1-6,3 × 1,8-3,6 mm, obovoide. Sementes $0,3-0,6 \times 0,2 \mathrm{~mm}$, castanho-claras, translúcidas a opacas, elipsoides, reticuladas, ápice apiculado.

Material examinado selecionado: Antonina, Usina Hidrelétrica Parigot de Souza, 12.XII.1991, fl., J.T. Motta 2409 (MBM). Arapoti, Rio das Cinzas, Barra dos Perdizes, 11.III.1960, fl., G. Hatschbach 6849 (UPCB). Balsa Nova, BR-277, próx. ao trevo com BR-376, 3.I.1999, fl., S.R. Ziller 1740 (MBM, EFC). Bituruna, Fazenda Etienne, 1.I.1956, fl., V. Stawiarski (R 76564). Campo Largo, Serra de São Luís do Purunã, próx. ao Pedágio da BR-277, 25²7'48'S, 49³9'3”O, 6.II.2013, fl., E.D. Lozano \& M. Selusniaki 1219 (MBM, NY, SP, UPCB). Campo Mourão, Fazenda Coamo, 3.I.1980, fl., J.M. Lima 813 (FUEL). Candói, Fazenda Capão Redondo, 2525'24”'S, 5148'11”'O, 12.XII.2013, fl., E.D. Lozano \& M.E. Engels 2289 (MBM). Carambeí, Rio São João, 2453'59'S, 507'49'O, 18.II.2013, fl. e fr., E.D. Lozano \& D.P. Saridakis 2632 (MBM, SP). Cascavel, BR-277, $2 \mathrm{~km}$ a leste de Cascavel, 14.III.1976, fl., G. Davidse 11251 (CTES, SP, RB). Cruzeiro do Oeste, Doradina, 30.X.1959, fl., R. Braga 8 (UPCB). Curitiba, Parque Náutico Iguaçu, 28.II.1984, fl., G. Hatschbach 48121 (MBM, HUCS). Diamante do Norte, Estação Ecológica do Caiuá, 5.XII.2001, fl., C.I.L.F. Rosa 131 (HUEM). Foz do Iguaçú, área do Incra, 14.II.1980, fl., Buttura 450 (MBM). Foz do Jordão, Águas de São Francisco, 2543'21'S, 2511'25'O, 7.II.2015, fl e fr., E.D. Lozano \& B.K. Canestraro 2930 (ICN, MBM, RB, SP, UPCB). General Carneiro, Galinhas, 10.II.1966, G. Hatschbach 13846 (HB, MBM, UPCB). Guaíra, Sete Quedas, 20.III.1982, fl., F.S. Muniz 419 (SP). Guarapuava, BR277 , campo em frente à concessionária Valtra-Shark, 2522'58'S, 51³0'39'O, 11.XII.2013, fl. e fr., E.D. Lozano \& M.E. Engels 2243 (MBM). Guaraqueçaba, Ilha de Superagui, trilha para praia deserta, $25^{\circ} 27^{\prime} 41^{\prime}$ 'S, 48¹3'57'O, 10.I.2014, fl., E.D. Lozano et al. 2547 (MBM). Guaratuba, Balneário Coroados, 14.II.1985, fl., C.A. Marafon 194 (PEL). Jaguariaíva, Parque Estadual do Cerrado, 24¹0'12'S, 4940'7”O, 29.XI.2013, fl. e fr., E.D. Lozano \& D.P. Saridakis 2061 (MBM, SP). Lapa, arredores do Parque Estadual do Monge, 2546'21"S, 4942'1'O, 14.XII.2013, fl., E.D. Lozano \& M.E. Engels 2362 (MBM). Luiziana, Estação Ecológica Luiziana, 9.IV.2010, fr., E.L. Siqueira 309 (FURB, HCF). Mandirituba, sem localidade, 28.II.1966, fr., G. 


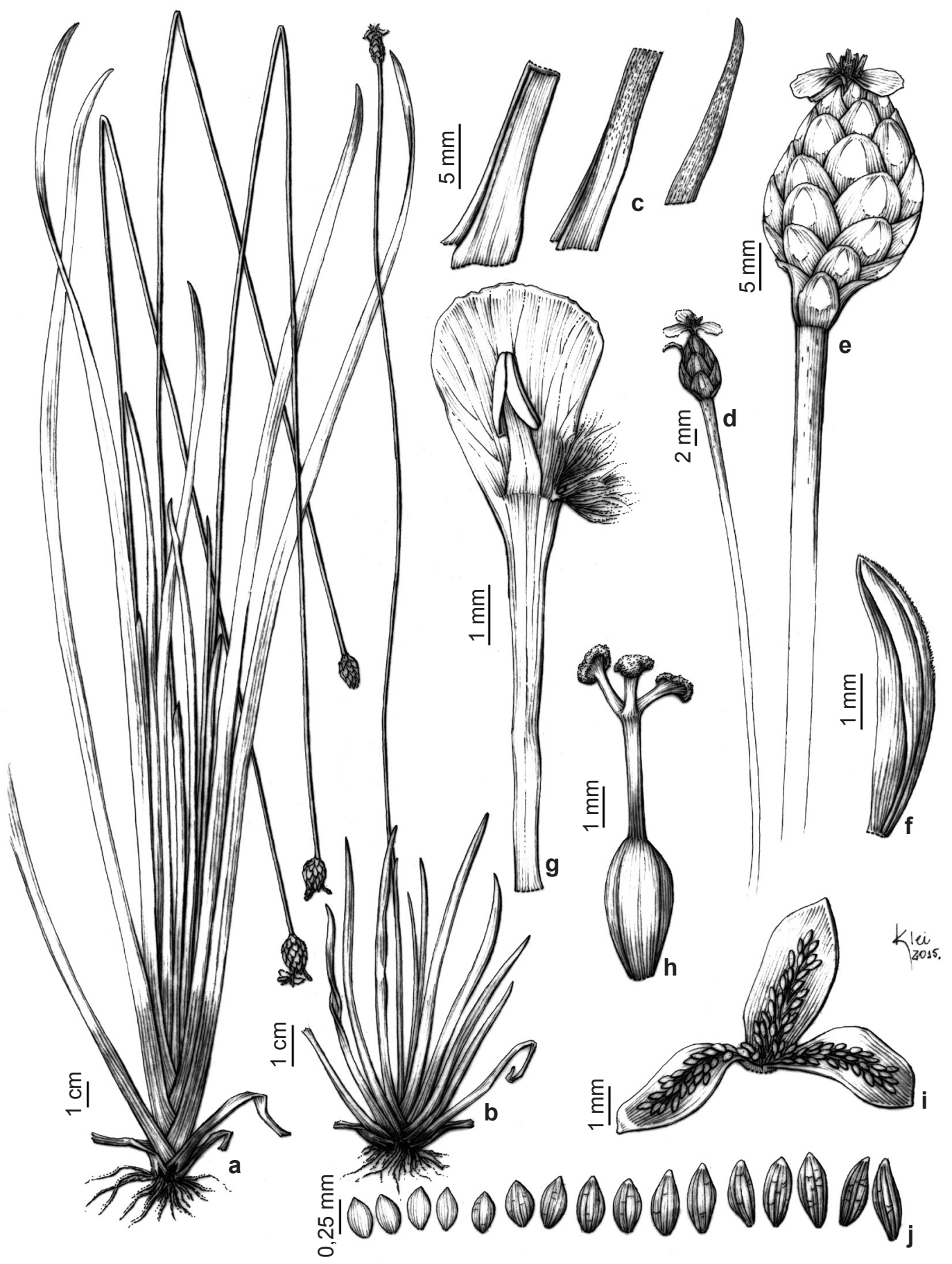

Figura 3 - a-j. Xyris jupicai - a. hábito de planta com base submersa; b. hábito de planta terrestre; c. seções da folha; d. espiga de planta terrestre; e. espiga de planta com base submersa; f. sépala lateral; g. pétala com estame e estaminódio; h. gineceu; i. cápsula com placentação parietal; j. variação morfológica das sementes.

Figure 3 - a-j. Xyris jupicai - a. habit of plant with submerged base; b. habit of terrestrial plant; c. leaf sections; d. spike of terrestrial plant; e. spike of plant with submerged base; f. lateral sepal; g. petal with stamen and staminode; h. gynoecium; i. capsule with parietal placentation; j. morphological variation of seeds. 
Hatschbach 13919 (HB, MBM). Matinhos, Caiobá, 5.XI.1947, fl., G. Tesmann 2611 (MBM). Mauá da Serra, Mata do Pinhão, 10.X.2008, E.M. Francisco 227 (FUEL). Morretes, Pilão de Pedra, 28.I.1982, fr., $R$. Kummrow 1693 (MBM, SP). Palmas, Refúgio de Vida Silvestre de Palmas, Fazenda São Pedro, 2631'32"S, 5140'28”O, 13.XII.2013, fl., E.D. Lozano \& M.E. Engels 2316 (MBM, SP). Palmeira, Rio Tibagi, 7.I.1904, fr., P. Dusén 3735 (R). Paranaguá, P.E. Floresta do Palmito, 25'35'5"S, 48'32'5"O, 1.II.2014, fl., E.D. Lozano et al. 2558 (MBM). Pinhais, Parque Newton Freire Maia, 10.II.2014, fl., R. Ristow 4120 (IRAI). Piraí do Sul, Fazenda Nova Era, 2423'55"S, 4951'21"O, 24.XI.2012, fl., E.D. Lozano et al. 1202 (MBM, RB, SP, UPCB). Piraquara, $22 \mathrm{~km}$ a leste de Curitiba, 4.I.1949, fl., G. Tesmann 3655 (PKDC). Ponta Grossa, Faz. Pinheirinhos, $25^{\circ} 6^{\prime} 8$ 'S, $50^{\circ} 1$ '31'O, 11.III.2014, fl. e fr., E.D. Lozano \& D.P. Saridakis 2683 (FLOR, HCF, MBM, RB, SP, UPCB) Pontal do Paraná, Balneário Shangrilá, 25'38'5"S, 48²5'34”'O, 6.I.2014, fl., E.D. Lozano et al. 2540 (ICN, MBM, RB, SP, UPCB). Quatro Barras, Rio Taquari, 19.III.1969, fl., G. Hatschbach 21282 (MBM). Rio Azul, 24.II.1972, fl., G. Hatschbach 29792 (MBM). Rio Negro, Campo do Tenente, 1.IV.1951, fl., G. Hatschbach 2201 (MBM). Rolândia, zona rural, 9.VI.1990, fl., E.J. Venancio (FUEL 8476). São Jeronimo da Serra, Reserva Indígena São Jeronimo, 18.III.2003, fl., K.L.V.R. Sá 455 (FUEL). São José dos Pinhais, Guaricana, 6.II.1972, fl., G. Hatschbach 38038 (MBM, SPF). São Mateus do Sul, Vila S' Ana, 8.II.1966, fl., G. Hatschbach 13785 (MBM). Sengés, Parque Ecológico Gruta da Barreira, 247'5"S, 49²1'51'O, 30.XI.2013, fr., E.D. Lozano \& D.P. Saridakis 2108 (MBM, RB, SP, UPCB). Teixeira Soares, proximidades de Teixeira Soares, 14.V.1988, fl., L.R. Czech (HUPG 1688). Terra Rica, beira de um braço da Represa de Rosana, 8.I.1991, fl., F. Barros 2125 (SP). Tibagi, P.E. Guartelá, 10.II.2004, fl., M.R.B. Carmo 726 (HUPG). Tijucas do Sul, campina a $46 \mathrm{~km}$ ao sul de Curitiba, 14.II.1978, fl., A. Krapovickas 33593 (CTES). Tuneiras do Oeste, Faz. Água do Índio, Rebio das Perobas, 26.I.2006, fl., M.G. Caxambu 960 (HCF). Turvo, Rio Marrecas, 17.II.2004, fl., G. Hatschbach 76756 (MBM). União da Vitoria, 27.VII.1967, fl., Koazicki 30 (MBM). Ventania, Campo de Fora, 22.III.2005, fl., D.A. Estevan 604 (FUEL).

Distribuição e hábitat: Xyris jupicai é uma espécie neotropical que ocorre desde o Canadá até a Argentina (Wanderley 2003). No Brasil ocorre em todos os estados e no Distrito Federal (Flora do Brasil 2020 em construção). É a espécie de Xyris mais comum no Paraná, ocorrendo desde o litoral até a bacia do Rio Paraná próximo à divisa com o Paraguai.

Durante as fases de campo foi observado que indivíduos em que a bainha ou parte dela estava submersa, essa porção possuía uma coloração avermelhada. Isso pode ser observado em Lozano et al. (2016b). Indivíduos que estavam mais próximos à água (poças e riachos) apresentavam um porte maior se comparado aos indivíduos que estavam em solo mais seco. Isso pode ser observado em indivíduos de uma mesma população, a cerca de 5 $m$ de distância uns dos outros.

Fenologia: pode ser encontrada com flores o ano todo.

Notas taxonômicas: Xyris jupicai faz parte de um complexo taxonômico juntamente com Xyris macrocephala Vahl. Estas espécies apresentam vários caracteres morfológicos em comum, como placentação parietal, bem como folhas dísticas, alargadas e com pontuações lineares. Essas espécies também possuem vários sinônimos.

Smith \& Downs (1965) trataram ambas como variedades de uma mesma espécie, considerando $X$. jupicai var. jupicai L.B.Sm. \& Downs e $X$. jupicai Rich. var. major (Mart.) L.B.Sm. \& Downs, separando-as apenas pelo tamanho da espiga e número de costelas no pedúnculo. Mais recentemente, Kral (1988) as reconheceu como duas espécies distintas $X$. jupicai e Xyris laxifolia Mart. Apesar de $X$. macrocephala ser o nome mais antigo, o autor decidiu não utiliza-lo por seu tipo apresentar mistura de material de diferentes espécies. Neste trabalho as duas espécies foram separadas especialmente pelo porte das plantas, e pela presença de pontuações lineares vermelhas nas folhas e base da bainha vermelha em $X$. laxifolia (X. macrocephala).

Wanderley (2011) reestabeleceu o nome $X$. macrocephala para a espécie até então reconhecida como $X$. laxifolia, pela prioridade de publicação. Nesse trabalho Wanderley discute a diferença entre estas duas espécies, separando-as por $X$. macrocephala apresentar porte maior e sementes fusiformes e opacas; e $X$. jupicai com um porte menor e sementes elipsoides e translúcidas. Esta é a classificação atualmente adotada para essas espécies (Silva \& Wanderley 2013).

Apesar de até o momento as duas espécies serem nomes válidos, tanto pela análise das exsicatas, quanto pelos estudos de campo, foi observada uma grande sobreposição desses caracteres utilizados para distinguir as duas espécies.

Por esses caracteres considerados diagnósticos para distinguir as duas espécies serem muito tênues e variáveis, e por geralmente os trabalhos serem baseados em indivíduos herborizados, possivelmente estas espécies se tratem de apenas 
uma entidade taxonômica. Deste modo, para esta flora, foi considerada apenas Xyris jupicai, por ser o epíteto mais antigo. Porém, ressalta-se a necessidade de ampliação dos estudos com exemplares que contemplem toda a distribuição das espécies, para uma possível sinonimização destes dois táxons.

Dentre as espécies que ocorrem no Paraná Xyris jupicai é facilmente reconhecida por apresentar folhas dísticas e alargadas e placentação parietal. Restos das flores podem ser persistentes no fruto.

11. Xyris lucida Malme, Ark. Bot., 13(3): 98, 1913. Fotos disponíveis em Lozano et al. (2016b).

Figs. 4a-f; 7k

Erva cespitosa, perene, base pouco dilatada, mucilagem hialina presente. Rizoma horizontal com entrenós curtos. Folhas 29-82 cm compr., espiraladas, eretas; bainha 6-14 × 0,93-1,33 cm, gradativamente dilatada para base, castanhofulgente, lisa, margem hialina, glabra; lâmina 23$68 \times 0,12-0,28 \mathrm{~cm}$, achatada, verde, avermelhada na base, lisa, margem glabra, ápice agudo. Lígula presente. Espata $11-18 \times 0,39-0,52 \mathrm{~cm}$, avermelhada, carena glabra, margem hialina, lâmina presente. Pedúnculo 39-93 × 0,13-0,17 cm, sub-cilíndrico, verde, glabro, 1-costelado, costelas glabras. Espiga 11-14,4 × 6,6-8,7 mm, elipsoide a obovoide, brácteas castanho-escuras, carena ausente, mácula lanceolada, verde, margem inteira, concolor, glabra; brácteas estéreis ca. 11, ovadas; brácteas florais ca. 20, obovadas. Flores com sépala anterior membranácea, avermelhada; sépalas laterais 7,1-8,8 mm compr., inclusas, estreito-oblanceoladas, sub-equilaterais, ápice obtuso, carena alargada, glabra a glabrescente, lacerada, principalmente da porção mediana ao ápice; lobo das pétalas ca. $8 \times 6,6 \mathrm{~mm}$, obovado a orbicular, margem erosa; estaminódios ca. 3,5 mm compr., densamente pilosos por todo ramo; estames ca. 4,4 mm compr., anteras oblongas; estilete ca. 7,1 mm compr., ramos ca. 2,9 mm compr.; placentação central-livre. Cápsula 5,4-5,8 × 2,1-2,4 mm, obovoide, fusiforme. Sementes ca. 1,2 × 0,3-0,4 $\mathrm{mm}$, castanho-avermelhadas, opacas, fusiformes, lanceoladas, estriadas, ápice apiculado.

Material examinado selecionado: Campina Grande do Sul, Serra da Bocaina, 14.VI.2000, fl., C.V. Roderjan 1691 (EFC). Guaratuba, Morro dos Perdidos, 25'53'23”S, 48 57'23”O, 12.II.2014, fl. e fr., E.D. Lozano et al. 2624 (FLOR, MBM, NY, SP, UPCB). Morretes, Torre da Prata, 2.III.2013, fl., M.L. Broto 972 (MBM, RB).
Distribuição e hábitat: espécie endêmica do Brasil, possuindo registros apenas nos estados do Paraná e Santa Catarina (Flora do Brasil 2020 em construção). Xyris lucida ocorre em campos de altitude da Serra do Mar, em geral entre 1.200 e $1.500 \mathrm{~m}$ de altitude, onde forma grandes populações.

Fenologia: pode ser encontrada com flores de outubro a março.

Notas taxonômicas: Xyris lucida é muito semelhante à $X$. piraquarae, por ambas apresentarem lâmina achatada e sépala laterais com carena glabra. Entretanto, diferenciam-se por $X$. lucida apresentar pedúnculo 1-costelado e sépalas laterais com carena distintamente lacerada, enquanto $X$. piraquarae possui o pedúnculo bialado e sépalas laterais com carena inteira.

12. Xyris metallica Klotzsch \& Seub., Fl. bras., 3(1): 213, 1855.

Fotos disponíveis em Lozano et al. (2016b).

Figs. 4g-1; 71

Erva cespitosa, perene, base pouco dilatada, mucilagem hialina ausente. Rizoma horizontal com entrenós curtos. Folhas 31-56 cm compr., espiraladas, eretas; bainha 12,6-16 × 0,63-0,79 $\mathrm{cm}$, gradativamente dilatada para base, castanhoamarelada, transverso-rugosa a lisa, margem hialina, ciliada a glabrescente, podendo apresentar tricomas longos na base; lâmina 18-42,2 $\times$ 0,22-0,38 cm, achatada, verde a castanha, lisa, estriada, margem escabro-ciliada a glabrescente, ápice agudo. Lígula ausente. Espata 22,3-28,9 $\times 0,33-0,49 \mathrm{~cm}$, castanho clara a avermelhada, carena curto-ciliada a glabra, margem hialina, lâmina presente. Pedúnculo 69,1-79,2 × 0,11-0,18 $\mathrm{cm}$, sub-cilíndrico, verde, liso com pontuações vermelhas, 1-costelado, costela curto-ciliada, tricomas castanhos. Espiga 8,8-10,6 × 6,9-7,4 mm, elipsoide a obovoide; brácteas castanho-escuras, as basais carenadas, mácula ausente, margem inteira, hialina caduca, glabra; brácteas estéreis ca. 10, elípticas; brácteas florais 10-22, oblongas. Flores com sépala anterior membranácea, avermelhada; sépalas laterais 5,7-6,8 mm compr., inclusas, oblanceoladas, inequilatarais, ápice obtuso, carena estreita, curto-ciliada, tricomas castanhos; lobo das pétalas ca. $5 \times 2,4 \mathrm{~mm}$, oblongo a obovado, margem erosa; estaminódios 1,7-4,2 mm compr., densamente pilosos; estames 1,5-5 mm compr., anteras sagitadas; estilete 5,6-6,1 mm compr, ramos 3,2-3,5 mm compr.; placentação basal. Cápsula ca. $5 \times 1,4 \mathrm{~mm}$, fusiforme. Sementes ca. $0,8 \times 0,3 \mathrm{~mm}$, 


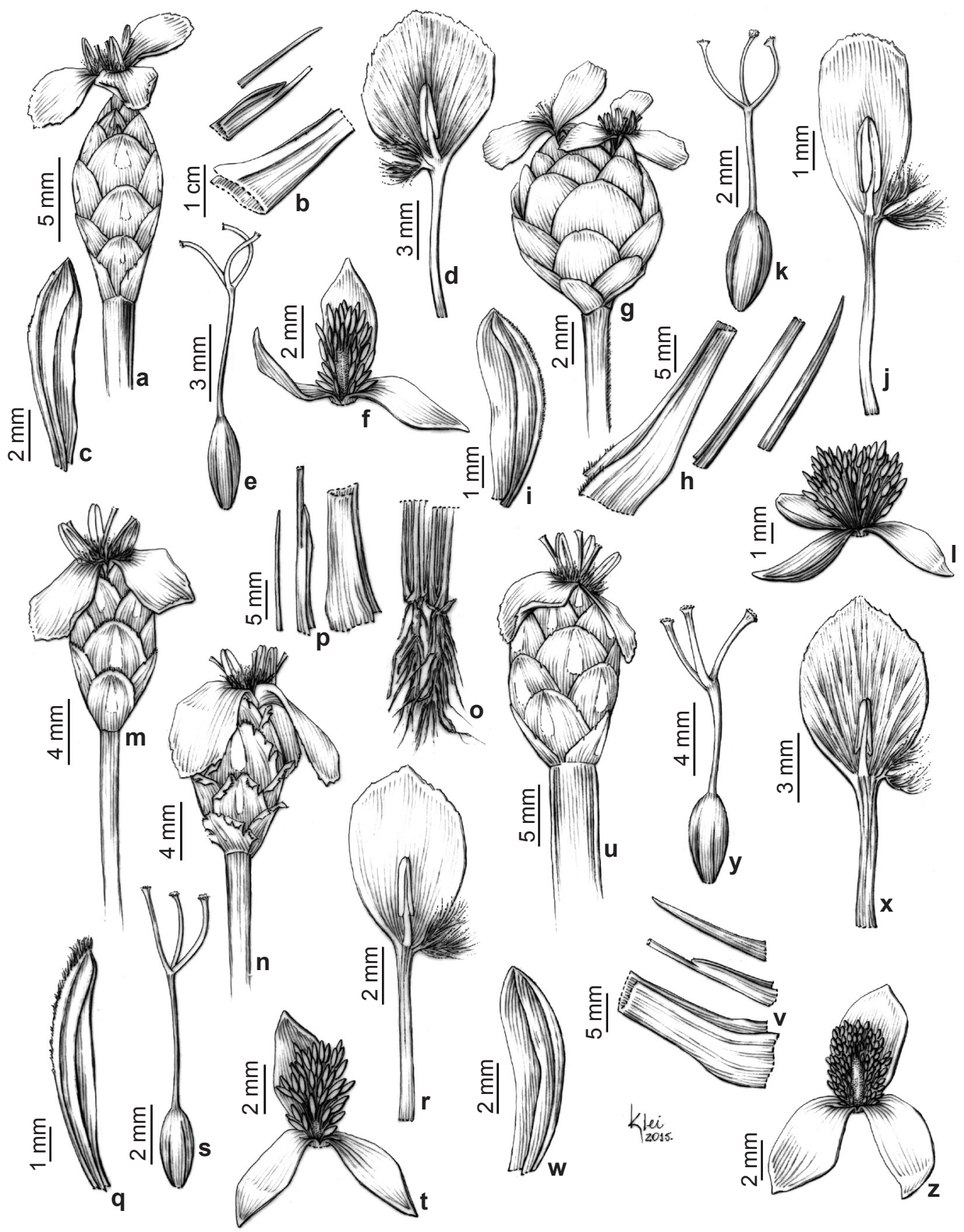

Figura 4 -a-f. Xyris lucida - a. espiga; b. seções da folha; c. sépala lateral; d. pétala com estame e estaminódio; e. gineceu; f. cápsula com placentação central-livre. g-l. Xyris metallica - g. espiga; h. seções da folha; i. sépala lateral; j. pétala com estame e estaminódio; $\mathrm{k}$. gineceu; 1 . cápsula com placentação basal. m-t. Xyris neglecta - m. espiga jovem; n. espiga madura; o. base com rizoma ereto; $p$. seções da folha; q. sépala lateral; r. pétala com estame e estaminódio; s. gineceu; t. cápsula com placentação suprabasal. u-z. Xyris piraquarae - u. espiga; v. seções da folha; w. sépala lateral; x. pétala com estame e estaminódio; y. gineceu; z. cápsula com placentação central-livre.

Figure 4 - a-f. Xyris lucida - a. spike; b. leaf sections; c. lateral sepal; d. petal with stamen and staminode; e. gynoecium; f. capsule with freecentral placentation. g-1. Xyris metallica - g. spike; h. leaf sections; i. lateral sepal; j. petal with stamen and staminode; k. gynoecium; 1 . capsule with basal placentation. m-t. Xyris neglecta - m. young spike; n. mature spike; o. erect rhizome; p. leaf sections; q. lateral sepal; r. petal with stamen and staminode; s. gynoecium; t. capsule with suprabasal placentation. u-z. Xyris piraquarae - u. spike; v. leaf sections; $\mathrm{w}$. lateral sepal; x. petal with stamen and staminode; y. gynoecium; z. capsule with free-central placentation. 
castanho-avermelhadas, translúcidas, fusiformes, multicosteladas, ápice apiculado.

Material examinado selecionado: Balsa Nova, Ponte dos Arcos, 5.I.2006, fl., C. Kozera 2816 (MBM, UPCB). Campo Mourão, arredores do polo industrial, bairro Lar Paraná, 244'21”'S, 52²5'49”O, 13.XI.2013, fl., E.D. Lozano \& E.L. Siqueira 1767 (FLOR, HCF, ICN, MBM, NY, RB, SP, UPCB). Candói, PR-560, estrada para Santa Clara, 25'33'26”'s, 51'30'2”O, 12.XII.2013, fl., E.D. Lozano \& M.E. Engels 2267 (MBM, SP). Guarapuava, BR-277, em frente à concessionária da John Deere, 25'22'24"S, 52 59'55"O, 11.XII.2013, fl., E.D. Lozano \& M.E. Engels 2266 (FLOR, HCF, ICN, MBM, NY, SP, UPCB). Palmeira, Córrego da Anta, 2.II.1975, fl., $B$. Hansen 10942 (CTES). Ponta Grossa, Vila Velha, 20.I.1965, fl., L.B. Smith \& R.M. Klein 14883 (FLOR, HBR, MBM, NY, R).

Distribuição e hábitat: Xyris metallica possui registros nas Regiões Sudeste, Centro-oeste e Nordeste, principalmente no bioma Cerrado (Wanderley 2003). Trata-se de um novo registro para o Paraná, que surge como limite austral de sua distribuição. Ocorre nas margens de rios lajeados e campos úmidos próximos a cursos d'água. As populações encontradas no presente levantamento, ou ocorrem muito próximas a áreas urbanas, ou encontram-se em pequenos fragmentos de vegetação nativa, o que representa grande ameaça a estas populações.

Fenologia: é encontrada com flores de dezembro a janeiro.

Notas taxonômicas: a espécie pode ser confundida com X. glandacea por possuir brácteas sem mácula e margem da lâmina, bem como as costelas do pedúnculo, curto-ciliadas. Diferencia-se desta por apresentar brácteas castanhas, sépalas laterais subequilaterais e estaminódios densamente pilosos. Também é muito similar morfologicamente a $X$. asperula, por ambas apresentarem espigas em geral ovoides com brácteas concolores e lâminas achatadas. Difere desta, por apresentar a margem da bainha glabra próximo a base, enquanto em $X$. asperula essa região apresenta tricomas longos.

13. Xyris neglecta L.A.Nilsson, Kongl. Svenska Vetensk.-Akad. Handl. 24(14): 45. 1892.

Fotos disponíveis em Lozano et al. (2016b).

Figs. 4m-t; $7 \mathrm{~m}$

Erva cespitosa, perene, base pouco dilatada, mucilagem hialina ausente. Rizoma ereto com entrenós longos ou horizontal com entrenós curtos. Folhas 19-130 cm compr., espiraladas, eretas; bainha $6,5-26 \times 0,71-1,39 \mathrm{~cm}$, gradativamente dilatada para base, castanho-clara a castanho- escura avermelhada, lisa, margem indistinta, glabra; lâmina 12,5-109 × 0,05-0,14 cm, subcilíndrica, verde, lisa a transverso-rugosa na base, margem glabra, ápice agudo. Lígula presente. Espata $12-25,5 \times 0,38-0,65 \mathrm{~cm}$, castanho-clara a castanho-escura, carena ausente, margem glabra, lâmina presente. Pedúnculo 53-137 × 0,07-0,12 cm, cilíndrico, verde, glabro, sem costelas. Espiga 8,9-14,2 × 5,2-8,6 mm, em geral elipsoide, podendo ser de ovoide a obovoide; brácteas castanhas, carena ausente, mácula lanceolada, acinzentada a verde, margem lacerada, concolor, castanho-pubescente a alvo-pubescente; brácteas estéreis ca. 10, obovadas; brácteas florais 18-28, obovadas. Flores com sépala anterior membranácea, avermelhada; sépalas laterais 5,8-8,6 mm compr., inclusas a levemente exsertas, estreito-oblanceoladas, sub-equilaterais, ápice obtuso, carena alargada, longo-ciliada, lanuginosa no ápice, tricomas alvos a avermelhados; lobo das pétalas $6,4-7,1 \times 3,9-4,9 \mathrm{~mm}$, obovado, margem erosa; estaminódios 2,6-3,6 mm compr., densamente pilosos por todo ramo; estames 3,2-3,3 $\mathrm{mm}$ compr., anteras oblongas; estilete 7,4-8,1 mm compr., ramos 2,8-3,3 mm compr.; placentação suprabasal a central-livre. Cápsula 5,1-5,8 $\times$ 1,9-2 mm, fusiforme. Sementes $1-1,2 \times 0,3 \mathrm{~mm}$, castanho-escuras, opacas, fusiformes, estriadas, ápice apiculado.

Material examinado selecionado: Arapoti, Rio das Cinzas, Barra dos Perdizes, 23.X.1961, fl., G. Hatschbach 8364 (HB, HBR, MBM, UPCB). Balsa Nova, Serra Sta. Ana, 1.XI.1969, fl., G. Hatschbach 22807 (MBM). Campo Largo, próx. ao pedágio da BR-277, 2527'49'S, 49³9'4'O, 6.XII.2013, fl., E.D. Lozano \& M. Selusniaki 1218 (MBM, NY, RB, SP). Candói, PR-560, estrada para Santa Clara, 25 33 '26”'S, 51059'55"O, 12.XII.2013, f1., E.D. Lozano \& M.E. Engels 2269 (MBM, NY, SP, UPCB). Carambeí, Rio São João, 2453'59'S, 507'49'O, 18.XI.2014, f1., E.D. Lozano \& D.P. Saridakis 2635 (MBM, SP). Castro, Rio Cunhaporanga, 17.XI.1988, fl., S.M. Silva 1647 (PKDC). Colombo, Rio Palmital, 1.XI.1973, fl., G. Hatschbach 33994 (MBM). Curitiba, Recanto das Araucárias, 9.XI.1987, fl., J.M. Silva 422 (MBM, UPCB). Guarapuava, BR-277, campo em frente à

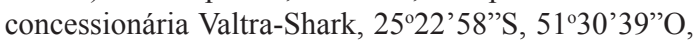
11.XII.2013, fl., E.D. Lozano \& M.E. Engels 2242 (HCF, MBM, NY, RB, SP). Jaguariaíva, Fazenda Garrote, 2422'56”'S, 4950'35”'O, 24.XI.2012, fl., E.D. Lozano et al. 1183 (HCF, ICN, MBM, NY, RB, SP). Lapa, arredores do Parque Estadual do Monge, 2546'21"S, 49²'’1'O, 14.XII.2013, f1., E.D. Lozano \& M.E. Engels 2360 (MBM, NY, SP, UPCB). Mallet, 11.XII.1966, fl., G. Hatschbach 15372 (MBM). Palmas, Refúgio de Vida 
Silvestre de Palmas, Fazenda São Pedro, 26³2'40"S, 51³9'15”O, 13.XII.2013, fl., E.D. Lozano \& M.E. Engels 2349 (MBM, NY, SP, UPCB). Palmeira, Recanto dos Papagaios, 18.XII.2013, fl., J.T. Motta 4169 (ALCB, FURB, HCF, MBM). Pinhais, Autódromo Pinhais, 26.XII.1973, fl., G. Hatschbach 33579 (MBM). Piraí do Sul, Fazenda Barbante, 2425'26"S, 4958'32"O, 28.XI.2013, fl., E.D. Lozano \& D.P. Saridakis 2006 (MBM, NY, SP, UPCB). Piraquara, próx. ao reservatório Piraquara II, 25³0'50”S, 49¹'23”O, 20.XI.2013, fl., E.D. Lozano \& M.G.L. Wanderley 1865 (HCF, ICN, MBM, NY, RB, SP, UPCB). Ponta Grossa, Parque Estadual de Vila Velha, 2514'51"S, 4959'30"O, 18.XII.2013, fr., E.D. Lozano 2451 (MBM, NY, SP, UPCB). Porto Amazonas, beira da BR-277, 25'28'11'S, 4945'0”'O, 3.XI.2013, fl., E.D. Lozano \& M.E. Engels 1627 (MBM, NY, SP, UPCB). São João do Triunfo, 7.XI.1967, fl., G. Hatschbach 17746 (MBM). São José dos Pinhais, Barro Branco, 11.XI.1965, fl., G. Hatschbach 13130 (HB, MBM, UPCB). São Mateus do Sul, foz do Rio Taquaral, 1.XII.1957, fl., G. Hatschbach 3912 (MBM). Tibagi, Parque Estadual do Guartelá, 2430'50”S, 50¹5'23”'O, 21.XII.2013, fl. e fr., E.D. Lozano \& B. Damasceno 2534 (MBM, NY, SP).

Distribuição e hábitat: Xyris neglecta é endêmica do Brasil e pode ser encontrada nos estados de Paraná, Santa Catarina e São Paulo (Flora do Brasil 2020 em construção). No Paraná, é muito frequente na região dos Campos Gerais, formando grandes populações em campos úmidos e margens de rios lajeados.

Fenologia: pode ser encontrada com flores de outubro a fevereiro.

Notas taxonômicas: Xyris neglecta apresenta uma grande amplitude de variação morfológica em relação ao porte e à base da lâmina, que pode ser de rugosa (E.D. Lozano 2242 [MBM], G. Hatschbach 15372 [MBM]) a lisa (E.D. Lozano 2360 [MBM], G. Hatschbach 8364 [MBM]). Esta variação também pode ocorrer conjuntamente no mesmo indivíduo (E.D. Lozano 2635 [MBM]). O indumento das sépalas laterais podem apresentar tricomas vermelhos (E.D. Lozano 2006 [MBM]) a brancos (E.D. Lozano 2360 [MBM]). Esta variação na coloração dos tricomas também pode estar presente no mesmo indivíduo (E.D. Lozano 1183 [MBM], G. Hatschbach 22807 [MBM]). Outra variação observada é a presença de rizoma ereto, especialmente quando ocorre sobre substrato constantemente encharcado.

É relacionada morfologicamente a Xyris regnellii e $X$. rigida por apresentar tricomas no ápice das sépalas laterais, mas é facilmente diferenciada destas por apresentar as brácteas laceradas com a margem pubescente.
14. Xyris piraquarae L.B.Sm. \& Downs, Arq. Bot. estado Sao Paulo, 4(2): 28, 1966.

Fotos disponíveis em Lozano et al. (2016b).

Figs. 4u-z; 7n

Erva cespitosa, perene, base pouco dilatada, mucilagem hialina presente. Rizoma horizontal com entrenós curtos. Folhas 46-112 cm compr., espiraladas, eretas; bainha 9-17 × 1,28-1,8 cm, gradativamente dilatada para base, castanho-clara a amarelada, lisa, margem hialina, glabra; lâmina 37-95 × 0,32-0,62 cm, achatada, verde, lisa, margem levemente espessada, glabra, ápice obtuso. Lígula presente. Espata 14-26 × 0,63-0,88 cm, castanho amarelada, carena apenas próximo ao ápice, margem hialina, lâmina presente. Pedúnculo 38-109 × 0,27-0,39 cm, sub-cilíndrico, verde, liso, bialado, costelas glabras. Espiga 11-17,6 $\times$ 6,5-13,1 mm, elipsoide a ovoide; brácteas castanhas, carena ausente, mácula ovada, verde, margem inteira a levemente lacerada, concolor, glabra; brácteas estéreis ca. 9, ovadas; brácteas florais ca. 30, obovadas. Flores com sépala anterior membranácea, avermelhada; sépalas laterais 7,2-9,9 mm compr., inclusas, oblanceoladas a estreito-oblanceoladas, sub-equilaterais, ápice obtuso, carena alargada para o ápice, glabra, inteira a levemente serreada próximo ao ápice; lobo das pétalas 7,6-8,4 × 3,5-4,8 mm, obovado a elíptico, margem erosa; estaminódios 3,1-3,3 mm compr., densamente pilosos por todo ramo; estames 3,9-5,3 mm compr., anteras oblongas; estilete 10,3-11,5 mm compr., ramos 4-4,2 mm compr.; placentação central-livre. Cápsula ca. $6,4 \times 2,5 \mathrm{~mm}$, obovoide. Sementes ca. 1,3 × 0,4 mm, castanho-escuras, opacas, fusiformes, estriadas, ápice apiculado.

Material examinado selecionado: Campina Grande do Sul, cume do Pico Caratuva, 2514'26'S, 4849'44”O, 23.I.2013, fl. e fr., E.D. Lozano et al. 1215 (MBM, NY, RB, SP). Piraquara, estrada Rio Taquari-Rio Divisa, 13.XI.1949, G. Hatschbach 1613 fl., (MBM Holótipo, PEL Isótipo). Quatro Barras, estrada da Graciosa-Rio Taquari, 25¹8'40"S, 48'56'1'O, 20.XI.2013, fl., E.D. Lozano \& M.G.L. Wanderley 1860 (MBM, NY).

Distribuição e hábitat: Xyris piraquarae é uma espécie endêmica do Paraná (Flora do Brasil 2020 em construção). Ocorre apenas na Serra do Mar, formando grandes populações nos campos de altitude, em geral acima dos $1.600 \mathrm{~m}$ de altitude.

Fenologia: pode ser encontrada com flores de outubro a fevereiro.

Notas taxonômicas: suas principais características são o pedúnculo bialado e a bainha amarelada. É similar morfologicamente a $X$. lucida, diferindo 
desta pelas características apresentadas nas notas taxonômicas da mesma.

15. Xyris regnellii L.A.Nilsson, Kongl. Svenska Vetensk.-Akad. Handl. 24(14): 43. 1892.

Fotos disponíveis em Lozano et al. (2016b).

Figs. 5a-e; 70

Erva cespitosa, perene, base pouco dilatada, mucilagem hialina ausente. Rizoma ereto, com entrenós longos ou horizontal com entrenós curtos. Folhas 25,3-67,6 cm compr., espiraladas, eretas; bainha $4,5-8,7 \times 0,56-0,81 \mathrm{~cm}$, gradativamente dilatada para base, castanho-escura, lisa, margem hialina, glabra; lâmina 20-60 × 0,04-0,05 cm, quadrada ou pelo menos em parte em corte transversal, verde, transverso-rugosa, margem levemente espessada nos ângulos, glabra, ápice agudo. Lígula presente. Espata 9,5-19,5 $\times$ $0,2-0,34 \mathrm{~cm}$, castanho escura, carena glabra, margem hialina, lâmina presente, longa ca. 1/3 do tamanho. Pedúnculo 41,5-79,5 × 0,06-0,11 $\mathrm{cm}$, sub-cilíndrico, verde a castanho, tranversorugoso, multi-costelado, costelas glabras. Espiga 7,5-11,2 × 4,8-7,7 mm, elipsoide a obovoide; brácteas castanho-escuras, carena ausente, mácula lanceolada, verde, margem inteira, concolor, glabra; brácteas estéreis ca. 8 , ovadas; brácteas florais ca. 18, ovadas. Flores com sépala anterior membranácea, avermelhada; sépalas laterais 4,8-6,8 mm compr., inclusas a levemente exsertas, oblanceoladas, inequilatarais, ápice agudo, carena estreita, densamente longo-ciliada, principalmente nos $2 / 3$ superiores, tricomas alvos a castanhoavermelhados; lobo das pétalas ca. $6 \times 2,4 \mathrm{~mm}$, obovado, margem erosa, estaminódios ca. $2 \mathrm{~mm}$ compr., densamente pilosos por todo ramo, estames ca. 2,7 mm compr., anteras oblongas; estilete 6,7 $\mathrm{mm}$ compr., ramos $2,5 \mathrm{~mm}$ compr.; placentação central-livre. Cápsula ca. 3,5 × 1,4 mm, elipsoide. Sementes ca. $0,9 \times 0,15 \mathrm{~mm}$, castanho-escuras, translúcidas, fusiformes, estriadas, ápice apiculado. Material examinado selecionado: Clevelândia, Fazenda Sant'Ana, 29.XII.1956, fl., L.B. Smith 9587 (HBR, R). Curitiba, Atuba, 16.XI.1960, fl., G. Hatschbach 7480 (MBM). General Carneiro, Fazenda Pizzato, banhado Curicaca, 1.XI.2005, fl., C. Bona 310 (UPCB).

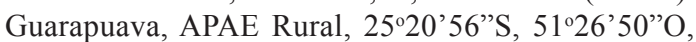
11.XII.2013, fl. e fr., E.D. Lozano \& M.E. Engels 2229 (FLOR, MBM, NY, RB, SP, UPCB). Mangueirinha, Estr. Palmas-Mangueirinha, 14.XII.1966, fl., G. Hatschbach 15472 (MBM, UPCB). Palmas, Refúgio de Vida Silvestre de Palmas, Fazenda Capão Alto, 26031'59'S, 51'36'25"O, 13.XII.2013, fl., E.D. Lozano \& M.E. Engels 2355 (MBM, NY, RB, SP). Ponta Grossa, nascente do Rio Tibagi, 6.XII.2008, fl., B.O. Andrade 52 (MBM).

Distribuição e hábitat: Xyris regnellii ocorre na Argentina no Paraguai (Wanderley 2003). No Brasil, é registrada para os estados de Minas Gerais, São Paulo e Região Sul (Flora do Brasil 2020 em construção). No Paraná, apresenta sua distribuição com poucos registros nos campos dos três planaltos. Ocorre principalmente em campos pouco drenados, com relva alta, em torno de um metro. É uma espécie pouco frequente no estado. Fenologia: é encontrada com flores de novembro a janeiro.

Notas taxonômicas: é a única espécie do gênero no Paraná a apresentar as lâminas quadrangulares em seção transversal, permitindo seu fácil reconhecimento apenas pelos caracteres vegetativos. É relacionada morfologicamente com Xyris rigida pelo porte, forma da espiga, brácteas com margem inteira e sépalas laterais que possuírem a carena densamente longo-ciliada, principalmente nos $2 / 3$ superiores. Entretanto é facilmente reconhecida pela forma da lâmina e por apresentar o pedúnculo multi-costelado.

16. Xyris rigida Kunth, Enum. Pl. 4: 15. 1843. Fotos disponíveis em Lozano et al. (2016b).

Figs. $5 \mathrm{f}-\mathrm{k} ; 7 \mathrm{p}$

Erva cespitosa, perene, base pouco dilatada, mucilagem hialina ausente. Rizoma horizontal com entrenós curtos. Folhas 24-54 cm compr., espiraladas eretas; bainha 4-7 × 0,85-0,9 cm, abruptamente dilatada na base, castanho-escura a negra, lisa, margem indistinta a hialina, glabra; lâmina 30-47 × 0,04-0,05 cm, sub-cilíndrica, verde a castanha, lisa, margem glabra, ápice acuminado. Lígula presente. Espata 9,5-10,4 ×0,25-0,27 cm, avermelhada, carena apenas próximo ao ápice, margem glabra, lâmina presente. Pedúnculo 46-54 × 0,07-0,08 cm, cilíndrico, verde, liso, glabro, sem costelas. Espiga 8,7-9,3 × 5,7-6,1 $\mathrm{mm}$, elipsoide a obovoide; brácteas castanhoescuras, carena ausente, mácula lanceolada, acinzentada ou verde, margem inteira, concolor, glabra; brácteas estéreis ca. 9, ovadas; brácteas florais ca. 12, obovadas. Flores com sépala anterior membranácea, avermelhada; sépalas laterais 5-5,3 $\mathrm{mm}$ compr., inclusas a levemente exsertas, elípticas a oblanceoladas, fortemente inequilaterais, ápice obtuso, carena estreita, densamente longo-ciliada, principalmente nos $2 / 3$ superiores, tricomas avermelhados; lobo das pétalas ca. 5,3 × 2,8 mm, obovado, margem erosa; estaminódios ca. $2,8 \mathrm{~mm}$ 


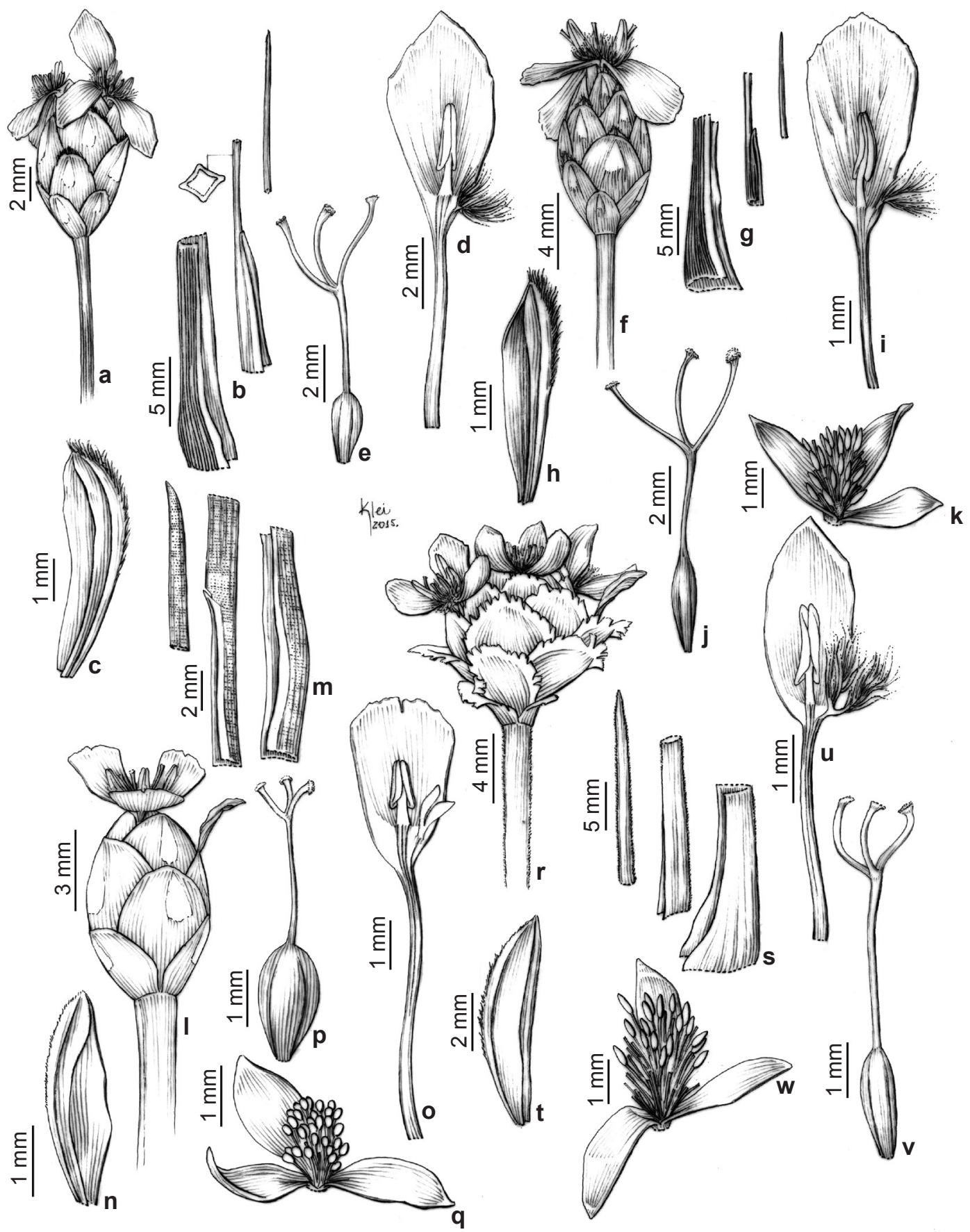

Figura 5 -a-e. Xyris regnellii - a. espiga; b. seções da folha com corte horizontal da lâmina; c. sépala lateral; $d$. pétala com estame e estaminódio; e. gineceu. f-k. Xyris rigida - f. espiga; g. seções da folha; h. sépala lateral; i. pétala com estame e estaminódio; j. gineceu; $\mathrm{k}$. cápsula com placentação suprabasal. l-q. Xyris savanensis - 1. espiga; m. seções da folha; $\mathrm{n}$. sépala lateral; o. pétala com estame e estaminódio; p. gineceu; q. cápsula com placentação basal. r-w. Xyris schizachne -r. espiga; $\mathrm{s}$. seções da folha; t. sépala lateral; u. pétala com estame e estaminódio; v. gineceu; w. cápsula com placentação basal. Figure 5 - a-e. Xyris regnellii - a. spike; b. leaf sections with horizontal cutting blade; $c$. lateral sepal; d. petal with stamen and staminode; e. gynoecium. f-k. Xyris rigida - f. spike; g. leaf sections; h. lateral sepal; i. petal with stamen and staminode; j. gynoecium; k. capsule with suprabasal placentation. 1-q. Xyris savanensis - 1 . spike; $\mathrm{m}$. leaf sections; $\mathrm{n}$. lateral sepal; o. petal with stamen and staminode; $\mathrm{p}$. gynoecium; q. capsule with basal placentation. r-w. Xyris schizachne $-\mathrm{r}$. spike; $\mathrm{s}$. leaf sections; t. lateral sepal; u. petal with stamen and staminode; v. gynoecium; w. capsule with basal placentation. 
compr., densamente pilosos por todo ramo; estames ca. 2,5 mm compr., anteras oblongas; estilete ca. 5,9 mm compr., ramos ca. 2,4 mm compr.; placentação suprabasal. Cápsula ca. $3,8 \times 1,5 \mathrm{~mm}$, obovoide. Sementes ca. $0,8 \times 0,3 \mathrm{~mm}$, castanho-claras, opacas, fusiformes, estriadas, ápice obtuso.

Material examinado selecionado: Candói, Fazenda Capão Redondo, 2525'24”S, 5148'11'O, 12.XII.2013, fl., E.D. Lozano \& M.E. Engels 2285 (FLOR, HCF, ICN, MBM, NY, SP, UPCB). Guarapuava, BR-277, campo em frente à concessionária Valtra-Shark, 2522'58'S, 51³0'39'O, 11.XII.2013, fl. e fr., E.D. Lozano \& M.E. Engels 2244 (FLOR, HCF, ICN, MBM, NY, SP, RB, UPCB).

Distribuição e hábitat: possui registros para Minas Gerais, São Paulo e todos os estados da Região Sul (Flora do Brasil 2020 em construção). Esta espécie se encontra Criticamente Ameaçada (Wanderley et al. 2013) e no Paraná só foram encontradas duas populações na região de Guarapuava, ambas fora de Unidades de Conservação. Ocorre em campo úmido sobre solo orgânico.

Fenologia: pode ser encontrada com flores em dezembro.

Notas taxonômicas: Xyris rigida faz parte de um complexo taxonômico, como já indicado por Wanderley (2003) e tem como espécies morfologicamente mais próximas $X$. neglecta e $X$. regnelli.

Xyris rigida pode ser diferenciada de $X$. neglecta por esta apresentar brácteas laceradas com a margem pilosa, sépalas laterais sub-equilaterais e bainha de castanho clara a castanho escura. Já em $X$. rigida as brácteas são inteiras e glabras, a sépala lateral é fortemente inequilateral e a bainha é negra. Xyris rigida também é morfologicamente similar a $X$. regnellii, mas difere desta pelas características citadas nas notas taxonômicas da mesma.

17. Xyris savanensis Miq., Linnaea, 18: 605, 1844. Fotos disponíveis em Lozano et al. (2016b).

Figs. 51-q; 7q

Erva solitária ou cespitosa formando pequenas touceiras, anual, base pouco dilatada, mucilagem hialina ausente. Rizoma horizontal com entrenós curtos. Folhas 1,3-16,5 cm compr., dísticas, eretas; bainha 0,5-4,5 × 0,03-0,42 $\mathrm{cm}$, pouco dilatada na base, castanho-escura a verde, transverso-rugosa, margem hialina, glabra; lâmina $0,8-11,5 \times 0,1-0,66 \mathrm{~cm}$, achatada, verde a vermelha, lisa a pouco rugosa, margem glabra a escabro-ciliada, levemente espessada, ápice acuminado. Lígula presente. Espata 1,3-8 $\times$ 0,15-0,34 cm, verde a vermelha, carena glabra, margem hialina, lâmina presente. Pedúnculo 3,4-60 $\times 0,02-0,12 \mathrm{~cm}$, cilíndrico a sub-cilíndrico, verde a castanho, tranverso-rugoso a liso, sem costelas a 2-costelado pelo menos em parte, costelas glabras. Espiga $3-11,7 \times 1,6-5,8 \mathrm{~mm}$, ovoide a globosa, brácteas castanhas, carena ausente, mácula ovada, verde a vermelha, margem inteira, concolor, glabra; brácteas estéreis ca. 4, obovadas; brácteas florais ca. 12-18, obovadas. Flores com sépala anterior membranácea, amarelada; sépalas laterais 2,3-3,4 mm compr., inclusas a levemente exertas, elípticas a lanceoladas, inequilatarais, ápice obtuso, carena estreita, esparsamente curto-ciliada, tricomas castanhos; lobo das pétalas ca. 3,5 × 1,8 mm, obcordado, margem erosa; estaminódios 0,7-1,6 mm compr., glabros; estames 1-1,7 mm compr., anteras oblongas; estilete $2,8 \mathrm{~mm}$ compr., ramos 1,2 mm compr.; placentação basal. Cápsula 2-2,9 $\times$ 1,2-2,1 mm, globosa a obovoide. Sementes 0,3-0,4 $\times 0,2-0,3 \mathrm{~mm}$, castanho-claras, translúcidas, globosas, estriadas, ápice apiculado.

Material examinado selecionado: Balsa Nova, próximo à Pousada Cainã, 25'26'19'S, 4943'28'O, 4.XII.2013, fl., E.D. Lozano 2152 (MBM, SP, UPCB). Campo Largo, próximo ao portal de São Luís do Purunã, 25'28'27'S, 4942'38'O, 4.XII.2013, fl., E.D. Lozano 2170 (MBM). Candói, Fazenda Capão Redondo, 2525'24'S, 5148'11'O, 12.XII.2013, fl., E.D. Lozano \& M.E. Engels 2288 (MBM, RB, SP, UPCB). Carambeí, estrada para o Rio São João, Alto Carambeí, 2554'21'S, 507'23”'O, 26.XI.2013, fl., E.D. Lozano \& D.P. Saridakis 1914 (MBM). Curitiba, 29.XI.1903, fl, P. Dusén 2336 (R). Ipiranga, Faxinal do Tanque, 20.XII.1970, fl., G. Hatschbach 25911 (MBM). Jaguariaíva, estrada para o Parque Estadual do Cerrado, 2412'26"S, 4941'1'O, 1.XII.2013, fl., E.D. Lozano 2129 (MBM, SP, UPCB). Lapa, arredores do Parque Estadual do Monge, 2546'21'S, 4942'1'O, 14.XII.2013, fl., E.D. Lozano \& M.E. Engels 2358 (MBM). Morretes, 8.V.1991, fl., Y.S. Kunyioshi 5424 (EFC). Palmeira, Fazenda Capão das Almas, 2519'19'S, 4950'37'O, 22.II.2013, fl., E.D. Lozano \& G. Felitto 1233 (MBM). Paranaguá, Floresta Estadual do Palmito, 2535'5”S, 48 32'5”O, 1.II.2014, fl., E.D. Lozano et al. 2557 (MBM). Piraí do Sul, Fazenda Barbante, propriedade da Iguaçu Celulose, 24²5'26”'S, 4958'32”'O, 28.XI.2013, fl., E.D. Lozano \& D.P. Saridakis 2005 (MBM, SP, UPCB). Piraquara, Borda do Campo, 17.XII.1950, fl., G. Hatschbach 2069 (MBM). Ponta Grossa, estrada para o Capão da Onça, 256'24"S, 50¹'23”'O, 20.XII.2013, fl., E.D. Lozano \& B. Damasceno 2515 (MBM). Pontal do Paraná, Pontal do Sul, 25.IX.1967, fl., G. Hatschbach 17233 (MBM). Sengés, Faz. Morungava Rio do Funil, 15.XII.1958, fl., G. Hatschbach 5375 (HBR, HUCP, MBM, PKDC). Telêmaco Borba, Harmonia, 15.XII.1951, fl., A. Mattos 4709 (MBM, PKDC, UPCB). Tibagi, P.E. Guartelá, 
25.V.1990, fl., Y.S. Kunyioshi 5538 (EFC). Tuneiras do Oeste, Faz. Água do Índio, Rebio das Perobas, 26.I.2006, fr., M.G. Caxambu 973 (HCF, RB).

Distribuição e hábitat: Xyris savanensis distribui-se por toda América do Sul, com exceção do Chile (Wanderley 2003). No Brasil, pode ser encontrada em todos os estados e no Distrito Federal (Flora do Brasil 2020 em construção). No Paraná, é uma das espécies mais comuns, ocorrendo nos três planaltos e na planície litorânea.

Ocorre principalmente em margens de riachos e rios lajeados, bem como barrancos em campos úmidos. Juntamente com $X$. hymenachne ocupa locais com solo exposto, onde não há forte competição por espaço.

Fenologia: é encontrada com flores de outubro a julho.

Notas taxonômicas: difere das demais espécies ocorrentes no Paraná pela presença de estaminódios glabros. Devido ao seu porte geralmente reduzido, pode ser confundida com Xyris tenella ou $X$. hymenachne, mas $X$. savanensis se distingue destas espécies por apresentar lígula.

18. Xyris schizachne Mart., Flora 24(2): 56. 1841. Fotos disponíveis em Lozano et al. (2016b).

Figs. 5r-w; 7r

Erva solitária ou cespitosa formando pequenas touceiras, perene base pouco dilatada, mucilagem hialina ausente. Rizoma horizontal com entrenós curtos. Folhas 16,5-41 cm compr., dísticas, eretas; bainha 7,5-17,5 × 0,39-1,14 cm, pouco dilatada na base, castanho-fulgente, lisa, com carena curto-ciliada, margem hialina, curto-ciliada, glabrescente; lâmina 8-28,5 × 0,21-0,62 cm, achatada, verde a castanha, lisa, margem escabrociliada, tricomas castanhos. Lígula ausente. Espata 16-25,5 × 0,34-0,86 cm, verde, carena curtociliada, margem hialina, com nervura proeminente próximo a margem, curto-ciliada, lâmina ausente. Pedúnculo 65,5-104 × 0,11-0,21 cm, subcilíndrico, verde, liso, 2-costelado, costelas curto-ciliadas, tricomas castanhos. Espiga 8,3-10,3 × 6,2-12 mm, obovoide a largo-elipsoide; brácteas castanhas, carena ausente, mácula ausente, margem lacerada, revoluta, castanho-avermelhada, glabra; brácteas estéreis ca. 4, obovadas; brácteas florais ca. 26, ovadas. Flores com sépala anterior membranácea, avermelhada; sépalas laterais 5,2-9,7 mm compr., inclusas, estreito-elípticas a estreito-oblanceoladas, sub-equilaterais, ápice agudo, carena alargada para o ápice, curto-ciliada, tricomas castanhos; lobo das pétalas ca. $3 \times 1,4 \mathrm{~mm}$, oblongo, margem lisa; estaminódios ca. 1,4 mm compr. densamente pilosos por todo ramo; estames ca. 1,7 mm compr., anteras sagitadas; estilete ca. 4,5 mm compr., ramos ca. 1,6 mm compr.; placentação basal. Cápsula ca. $3,7 \times 1,5 \mathrm{~mm}$, obovoide. Sementes ca. $0,8 \times 0,2$ $\mathrm{mm}$, castanho-escuras, translúcidas, fusiformes, estriadas, ápice apiculado.

Material examinado selecionado: Campo Mourão, arredores do Polo Industrial, bairro Lar Paraná, 244'21'S, 52'25'49”'O, 12.XI.2013, fl., E.D. Lozano \& E.L. Siqueira 1761 (MBM, SP). Candói, Fazenda Capão Redondo, 2525'24”S, 5148'11'O, 12.XII.2013, fl., E.D. Lozano \& M.E. Engels 2286 (MBM, NY, SP, UPCB). Carambeí, Rio São João, 2453'59'S, 507'49”'O, 18.II.2014, fr., E.D. Lozano \& D.P. Saridakis 2633 (MBM, SP, UPCB). CIANORTE, Nova Brasília, estrada boiadeira, 26.VIII.2005, fl., M.G. Caxambu 834 (HCF, MBM). Clevelândia, Fazenda Sant'Ana, 29.XII.1956, fl., L.B.Smith 9590 (HBR, R). Curitiba, Capão da Imbuia, 5.XI.1957, fl., R. Lange 1043 (PKDC). Jaguariaíva, estrada para o Parque Estadual do Cerrado, 2412'26”S, 4941'1'O, 1.XII.2013, fl., E.D. Lozano 2124 (MBM). Ipiranga, Faxinal do Tanque, 20.XII.1971, fl., G. Hatschbach 25897 (MBM). Lapa, Rio Passa Dois, 15.II.1967, fl., G. Hatschbach 15975 (HB, MBM). Mangueirinha, Estr. Palmas-Mangueirinha, 14.XII.1966, fl., G. Hatschbach 15468 (MBM, UPCB). Marmeleiro, Estrada Marmeleiro-Campo Ere, 21.II.1971, fl., G. Hatschbach 26422 (MBM). Mauá da Serra, Mata do Pinhão, 7.XI.2007, fl., V.M. Cotarelli 387 (FUEL). Palmas, Refúgio de Vida Silvestre de Palmas, Fazenda São Pedro, 26³1'32"S, 5140'28'O, 13.XII.2013, fr., E.D. Lozano \& M.E. Engels 2317 (MBM, SP, UPCB). Palmeira, Recanto dos Papagaios, 26.XI.2003, fl., A.C. Cervi 8584 (UPCB). Piraí do Sul, Chácara Santa Rita da Serra, 2427'59'S, 50¹'42”O, 26.XI.2013, fl., E.D. Lozano \& D.P. Saridakis 1883 (MBM). Ponta Grossa, Capão Grande, 21.XII.1903, fl, P. Dusén 3737 (R). São Jeronimo da Serra, Reserva Indígena São Jeronimo, 27.V.2002, fl., K.L.V.R. Sá $167 b$ (UEC). Sengés, PR-151, Rio Funil, 24'7'20'S, 49²3'28'O, 30.XI.2013, fl., E.D. Lozano \& D.P. Saridakis 2104 (HCF, ICN, MBM, NY, SP, UPCB). Telêmaco Borba, Cidade Nova, 13.XII.1951, fl., A. Mattos 4747 (PKDC).

Distribuição e hábitat: Xyris schizachne ocorre na Argentina, Brasil e Paraguai (Wanderley 2003). No Brasil é encontrada nos estados: Bahia, Goiás, Minas Gerais, Mato Grosso do Sul, Mato Grosso, Paraná, Rio Grande do Sul, Rio de Janeiro, Santa Catarina, São Paulo e Tocantins (Flora do Brasil 2020 em construção). No Paraná, apresenta ampla distribuição, com registros nos três planaltos, porém é pouco comum encontrá-la em campo. Geralmente ocorre em locais onde há constante fluxo de água, como em margem de rios lajeados, próximo a nascentes em meio ao campo e banhados. 
Fenologia: é encontrada com flores de novembro a fevereiro. Foi observada com flores abertas apenas pela manhã.

Notas taxonômicas: diferencia-se das outras espécies ocorrentes no Paraná por apresentar características bem distintas, como margem das lâminas e costela do pedúnculo curto-ciliadas, brácteas com margem avermelhada, revoluta e lacerada, e espata com três nervuras proeminentes curto-ciliadas.

19. Xyris stenophylla L.A.Nilsson, Kongl. Svenska Vetensk.-Akad. Handl. 24(14): 46. 1892.

Fotos disponíveis em Lozano et al. (2016b).

Figs. 6a-g; $7 \mathrm{~s}$

Erva cespitosa, perene, base pouco dilatada, mucilagem hialina ausente. Rizoma horizontal com entrenós longos. Folhas 11-49 cm compr., espiraladas, eretas, fortemente torcidas; bainha $2,5-6 \times 0,21-0,48 \mathrm{~cm}$, pouco dilatada na base, castanho-clara, lisa, margem hialina, tricomas longos na base; lâmina 8,5-44 ×0,04-0,08 cm, achatada a filiforme, verde a castanha, lisa, margem glabra, ápice acuminado. Lígula presente. Espata $6-12 \times 0,18-0,24 \mathrm{~cm}$, verde a castanho clara, carena glabra, margem hialina, lâmina presente. Pedúnculo 23,5-64,5 × 0,03-0,09 cm, cilíndrico, verde a castanho, liso, sem costelas. Espiga 7,2-8,8 × 3,5-6,4 mm, obovoide; brácteas castanhas a castanho-escuras, carena ausente, mácula ausente, margem inteira, concolor, glabra; brácteas estéreis 4, ovadas; brácteas florais ca. 4, ovadas. Flores com sépala anterior membranácea, avermelhada; sépalas laterais 5,5-7,5 mm compr., inclusas, oblanceoladas, elípticas a lanceoladas, equilaterais, ápice agudo, carena estreita, laceradofimbriada, porção superior avermelhada, tricomas se presentes castanhos; lobo das pétalas ca. 5,8 $\times$ $3,8 \mathrm{~mm}$, obovado, margem erosa; estaminódios ca. 2,3 mm compr., densamente pilosos por todo ramo; estames ca. 3,8 mm compr., anteras oblongas; estilete 7,7 mm compr., ramos 2,9 mm compr.; placentação suprabasal. Cápsula ca. $4 \times 1,5 \mathrm{~mm}$, estreito obovoide. Sementes ca. $1,1 \times 0,2 \mathrm{~mm}$, castanho-avermelhadas, translúcidas, fusiformes ou lanceoladas, estriadas, ápice atenuado.

Material examinado selecionado: Balsa Nova, Fazenda Tamanduá, 2532'19'S, 4942'53”O, 4.XII.2013, fl., E.D. Lozano 2138 (FLOR, HCF, ICN, MBM, NY, RB, SP, UPCB). Campina Grande do Sul, próximo ao cume do Pico Itapiroca, $25^{\circ} 14$ '44”S, 48 50' 5”O, 22.I.2014, fl., E.D. Lozano et al. 2555 (FLOR, HCF, MBM, NY, RB, SP, UPCB). Campo Largo, próximo ao portal de São
Luís do Purunã, 25'28’27’S, 4942’38”O, 4.XII.2013, f1., E.D. Lozano 2169 (MBM). Carambeí, estrada para o Rio São João, Alto Carambeí, 2454'21'’S, 507'23”O, 2.XI.2013, fl., E.D. Lozano \& M.E. Engels 1699 (MBM, NY, UPCB). Curitiba, Atuba, 16.XI.1960, fl., G. Hatschbach 7470 (MBM, HBR). Guaratuba, Morro dos Perdidos, 25'53'23”S, 48 57'23”'O, 12.II.2014, fl., E.D. Lozano et al. 2620 (MBM, NY, SP, UPCB). Morretes, conjunto Marumbi, Pico Boa Vista, 25'27'27'S, 48'55'43"O, 9.II.2014, fl. e fr., E.D. Lozano \& M.L. Brotto 2618 (MBM, NY, SP, UPCB). Palmeira, Fazenda Boiada, $25^{\circ} 17^{\prime} 8^{\prime \prime}$ 'S $49^{\circ} 51^{\prime} 45^{\prime \prime}$ 'O, 19.XII.2013, fl., E.D. Lozano 2474 (MBM, NY, SP, UPCB). Piraquara, próx. ao reservatório Piraquara II, $25^{\circ} 30^{\prime} 50^{\prime}$ 'S, 49 $9^{\circ} 1^{\prime 2} 28^{\prime \prime} \mathrm{O}$, 29.X.2013, fl., E.D. Lozano \& E.C. Smidt 1585 (HCF, MBM, NY, SP, UPCB). Ponta Grossa, estrada para o Capão da Onça, 25'6'24”S, 50¹'23”O, 20.XII.2013, fl., E.D. Lozano \& B. Damasceno 2513 (MBM, SP, UPCB). Porto Amazonas, margem da BR-277, 25'28'11'S, $49^{\circ} 45^{\prime}$ '”'O, 3.XI.2013, fl., E.D. Lozano \& M.E. Engels 1628 (MBM). São José dos Pinhais, Mergulhão, 30.XI.1988, fl., J. Cordeiro 593 (MBM). Tibagi, São Bento, Rincão das Pedras, 8.I.1880, f1., Schwacke 2491 (RB). Tijucas do Sul, Serra do Papanduva, 15.XII.1997, fl., O.S. Ribas 2156 (MBM).

Distribuição e hábitat: Xyris stenophylla é endêmica do Brasil. Ocorre na Região Sul e nos estados de Minas Gerais, Rio de Janeiro e São Paulo (Flora do Brasil 2020 em construção). No Paraná, é encontrada nos Campos Gerais e nos campos altomontanos da Serra do Mar.

Ocorre preferencialmente em campos úmidos com solo predominantemente orgânico e forma densas touceiras. É uma das poucas espécies do gênero que ocorre no cume das montanhas da Serra do Mar, podendo ser encontrada a $1850 \mathrm{~m}$ de altitude.

Fenologia: é encontrada com flores de outubro a fevereiro.

Notas taxonômicas: é similar morfologicamente a Xyris uninervis, por apresentar brácteas sem mácula e folha com lígula. Diferencia-se desta, por apresentar rizoma horizontal com entrenós longos e sépalas laterais inclusas, enquanto em $X$. uninervis o rizoma horizontal possui entrenós curtos e as sépalas laterais são exsertas.

20. Xyris tenella Kunth, Enum. Pl. 4: 9. 1843. Fotos disponíveis em Lozano et al. (2016b).

Figs. 6h-n; $7 \mathrm{t}$

Erva cespitosa, perene, base pouco dilatada, mucilagem hialina ausente. Rizoma horizontal com entrenós curtos. Folhas $0,8-4,5 \mathrm{~cm}$ compr., dísticas, eretas; bainha $0,4-2,5 \times 0,16-0,27 \mathrm{~cm}$, gradativamente dilatada para base, castanho-clara, 


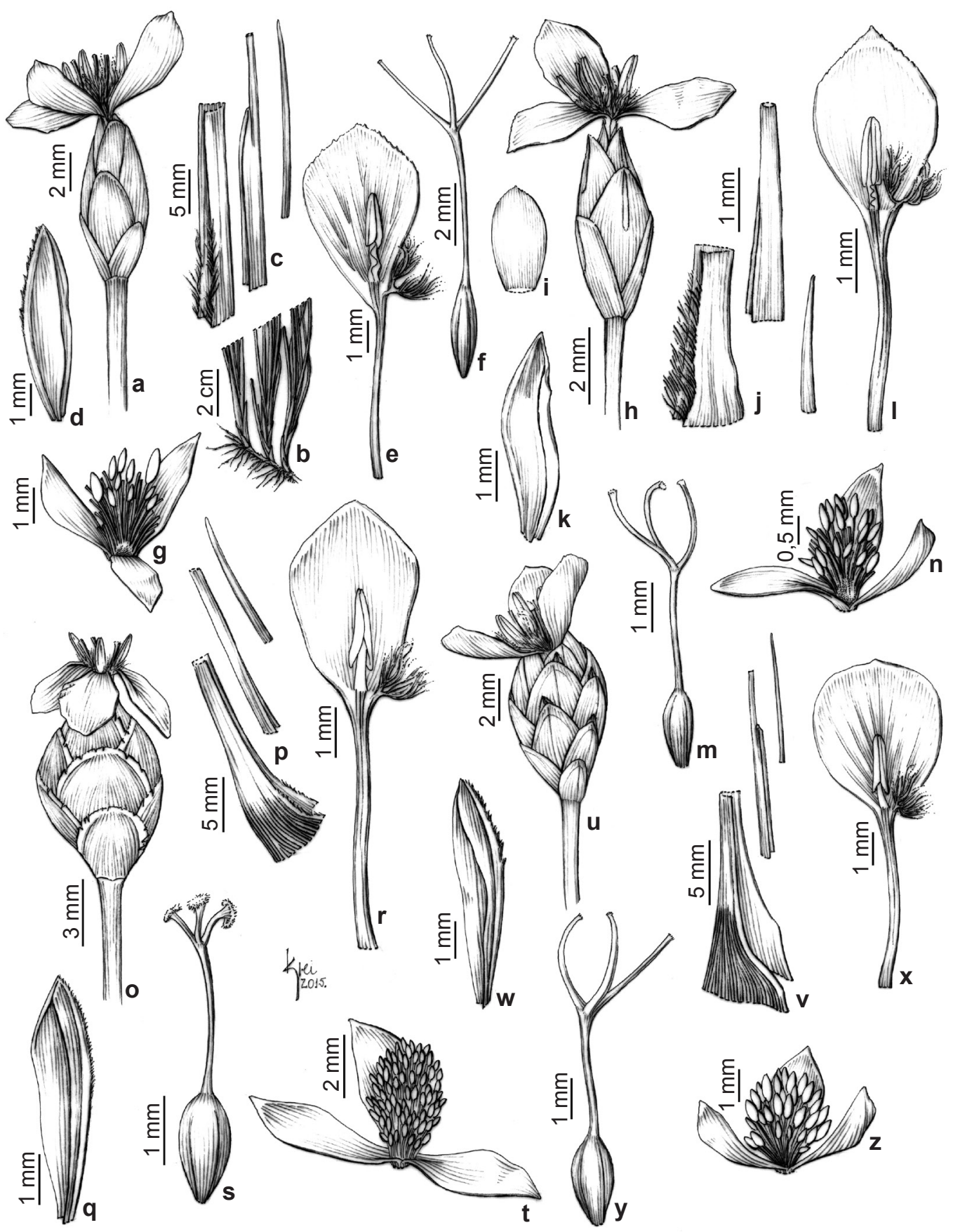

Figura 6 - a-g. Xyris stenophylla - a. espiga; b. base da planta; c. seções da folha; d. sépala lateral; e. pétala com estame e estaminódio; f. gineceu; g. cápsula com placentação suprabasal. h-n. Xyris tenella - h. espiga; i. bráctea sem mácula; j. seções da folha; k. sépala lateral; 1. pétala com estame e estaminódio; $\mathrm{m}$. gineceu; n. cápsula com placentação suprabasal. o-t. Xyris tortula - o. espiga; p. seções da folha; q. sépala lateral; r. pétala com estame e estaminódio; s. gineceu; t. cápsula com placentação basal. u-z. Xyris uninervis - u. espiga; v. seções da folha; w. sépala lateral; x. pétala com estame e estaminódio; y. gineceu; z. cápsula com placentação basal.

Figure 6 - a-g. Xyris stenophylla - a. spike; b. rhizome; c. leaf sections; d. lateral sepal; e. petal with stamen and staminode; f. gynoecium; g. capsule with suprabasal placentation. h-n. Xyris tenella - h. spike; i. unblemished bracts; j. leaf sections; k. lateral sepal; 1 petal with stamen and staminode; m. gynoecium; n. capsule with suprabasal placentation. o-t. Xyris tortula - o. spike; p. leaf sections; q. lateral sepal; r. petal with stamen and staminode; s. gynoecium; t. capsule with basal placentation. u-z. Xyris uninervis - u. spike; v. leaf sections; w. lateral sepal; x. petal with stamen and staminode; y. gynoecium; z. capsule with basal placentation. 
lisa, margem hialina, tricomas longos na base; lâmina $0,8-2,5 \times 0,04-0,09 \mathrm{~cm}$, achatada, verde a castanha, lisa, margem glabra, ápice agudo. Lígula ausente. Espata $1-4 \times 0,08-0,15 \mathrm{~cm}$, verde, carena glabra, margem hialina, lâmina ausente. Pedúnculo 6,5-25,5 × 0,03-0,05 cm, sub-cilíndrico, verde, liso, com pontuações, 2-costelado, costelas glabras. Espiga 4,5-6,1 × 1,5-3,6 mm, elipsoide a obovoide; brácteas castanhas a amareladas, as basais carenadas, mácula estreito-lanceolada ou ausente, quando presente avermelhada, margem castanho-avermelhada, glabra; brácteas estéreis ca. 4, lanceoladas; brácteas florais ca. 4, ovadas. Flores com sépala anterior membranácea, avermelhada; sépalas laterais 3,4-5 $\mathrm{mm}$ compr., inclusas, lanceoladas, equilaterais ou sub-equilaterais, ápice agudo, carena estreita, glabra; lobo das pétalas ca. 3,1 × 1,4 mm, obovado, margem erosa; estaminódios ca. 1,2 $\mathrm{mm}$ compr., pilosos por todo ramo; estames ca. 1,6 $\mathrm{mm}$ compr., anteras oblongas; estilete ca. 4,5 mm compr., ramos ca. 2 mm compr.; placentação suprabasal. Cápsula ca. $2,8 \times 1,5 \mathrm{~mm}$, obovoide. Sementes ca. $0,5 \times 0,2$ $\mathrm{mm}$, castanho-avermelhadas, translúcidas, ovoides ou obovoides, estriadas, ápice apiculado.

Material examinado selecionado: Balsa Nova, 22.IV.2006, fr., C. Kozera 3144 (MBM, UPCB). Carambeí, estrada para o Rio São João, 2554'21"S, $50^{\circ} 7$ '23”'O, 26.XI.2013, fl., E.D. Lozano \& D.P. Saridakis 1912 (MBM, NY, SP, UPCB). Jaguariaíva, estrada para

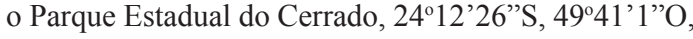
1.XII.2013, fl. e fr., E.D. Lozano 2130 (MBM, NY, SP, UPCB). Lapa, arredores do Parque Estadual do Monge, 2546'21"'S, 4942'1'O, 14.XII.2013, f1., E.D. Lozano \& M.E. Engels 2361 (MBM, NY, SP, UPCB). Palmeira,

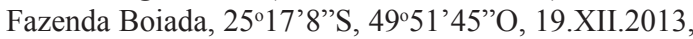
f1., E.D. Lozano 2477 (MBM, NY, SP, UPCB). Piraí do Sul, Chácara Santa Rita da Serra, 2427'59"S, 50'1'42"O, 3.IX.2013, fl., E.D. Lozano \& D.P. Saridakis 1486 (FLOR, HCF, ICN, MBM, NY, RB, SP, UPCB). Ponta Grossa, Rod. do Café, Rio Tibagi, 12.XII.1965, fl., R. Reitz 17501 (FLOR). Sengés, Rio Cajuru ao lado da ponte, 4.XII.1988, fr., P.M. Ruas (FUEL 6035). Tibagi, Parque Estadual do Guartelá, 2434'3"S, 50¹5'19"O, 21.XII.2013, fl., E.D. Lozano \& B. Damasceno 2536 (MBM, NY, SP, UPCB).

Distribuição e hábitat: Xyris tenella é amplamente distribuída na América do Sul, ocorrendo no Brasil, Guiana, Guiana Francesa, Paraguai e Peru (Wanderley 2003). No Brasil, ocorre em todas as regiões, tendo o Paraná como seu limite austral de distribuição (Flora do Brasil 2020 em construção). No Paraná, ocorre apenas nos Campos Gerais.

É a menor espécie de Xyris encontrada no Paraná, com as folhas nunca ultrapassando $5 \mathrm{~cm}$.
No estado, ocorre preferencialmente em locais onde há a deposição de matéria orgânica em afloramentos rochosos em que há um constante fluxo de água, ou barrancos úmidos e na margem de rios lajeados.

Fenologia: é encontrada com flores de novembro a janeiro.

Notas taxonômicas: durante a análise dos espécimes de Xyris tenella do Paraná, foram encontrados dois morfotipos. Nas populações encontradas no estado, os espécimes geralmente apresentam brácteas castanhas com uma mácula estreito-lanceolada (Fig. 6h). Porém, foi encontrada uma população em que a bráctea é amarelada e sem mácula (Fig. 6i) (E.D. Lozano \& D.P. Saridakis $1486[\mathrm{MBM}])$. Essa variação na coloração da bráctea, bem como a presença ou ausência de mácula já havia sido observada por Silva \& Wanderley (2013).

Dentre as espécies que ocorrem no Paraná, pode ser confundida $\operatorname{com} X$. savanensis pelo porte, diferindo desta pelas características apresentadas nas notas taxonômicas da mesma.

21. Xyris tortula Mart., Flora 24(2): 55. 1841. Fotos disponíveis em Lozano et al. (2016b).

Figs. 6o-t; $7 \mathrm{u}$

Erva solitária ou cespitosa, anual, base dilatada, sub-bulbosa, mucilagem hialina ausente. Rizoma horizontal com entrenós curtos, raro ereto com entrenós longos. Folhas 9,5-41 cm compr., espiraladas, eretas, fortemente torcidas; bainha 2,5-10 × 0,69-1,73 cm, abruptamente dilatada na base, castanho-clara, avermelhada para base, lisa, margem hialina, ciliada apenas na base; lâmina 7-31 × 0,18-0,27 cm, achatada, verde, lisa, nervuras conspícuas, margem glabra, ápice acuminado. Lígula ausente. Espata 4,5-20 × $0,21-0,35 \mathrm{~cm}$, verde, avermelhada na base, carena glabra, margem hialina, lâmina ausente. Pedúnculo 16,5-93 × 0,07-0,14 cm, sub-cilíndrico, verde, liso, levemente estriado, 1-costelado, costelas glabras a escabras. Espiga 5,9-10,9 × 0,7-6,8 mm, globosa a largo-elipsoide, abrindo mais de uma flor por vez; brácteas castanho-escuras, muitas vezes com mancha negra próximo a base, carena ausente, mácula ausente, margem lacerada, hialina, geralmente caduca, glabra; brácteas estéreis ca. 6 ovadas; brácteas florais ca. 14-18 obovadas. Flores com sépala anterior membranácea, castanha; sépalas laterais 4,3-5,7 mm compr., inclusas, elípticas a oblanceoladas, inequilatarais a fortemente inequilaterais, ápice obtuso, carena estreita, curto-ciliada, tricomas castanhos; lobo 

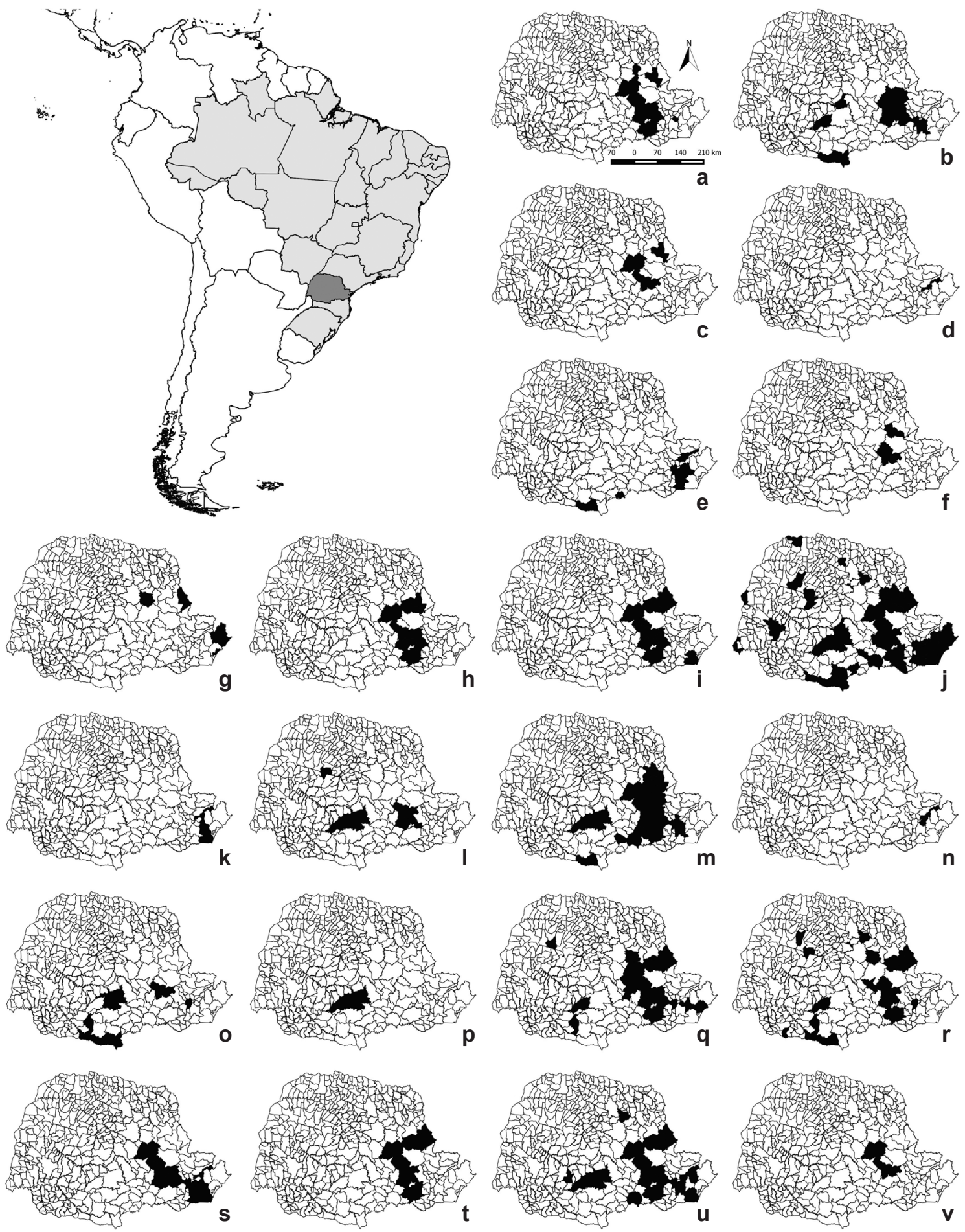

Figura 7 - a-v. Mapa de distribuição das espécies no paraná indicando os municípios que ocorrem - a. Xyris asperula; b. X. capensis; c. Xyris cervii; d. X. dissitifolia; e. X. dusenii; f. X. glandacea; g. X. guaranitica; h. X. hatschbachii; i. X. hymenachne; j. X. jupicai; k. X. lucida; 1. X. metallica; m. X. neglecta; n. X. piraquarae; o. X. regnellii; p. X. rigida; q. X. savanensis; r. X. schizachne; s. X. stenophylla; t. X. tenella; u. X. tortula; v. X. uninervis.

Figure 7 - a-v. Distribution map species in paraná indicating the municipalities that occur - a. Xyris asperula; b. X. capensis; c. Xyris cervii; d. X. dissitifolia; e. X. dusenii; f. X. glandacea; g. X. guaranitica; h. X. hatschbachii; i. X. hymenachne; j. X. jupicai; k. X. lucida; 1. X. metallica; m. X. neglecta; n. X. piraquarae; o. X. regnellii; p. X. rigida; q. X. savanensis; r. X. schizachne; s. X. stenophylla; t. X. tenella; u. X. tortula; v. X. uninervis. 
das pétalas $4 \times 3,5 \mathrm{~mm}$, obovado, margem erosa; estaminódios ca. 1,8 mm compr., densamente pilosos por todo ramo; estames ca. 2,1 mm compr., anteras sagitadas; estilete ca. 4,1 mm compr., ramos ca. 1,1 mm compr.; placentação basal. Cápsula ca. $4-5,2 \times 2-2,3 \mathrm{~mm}$, oblonga. Sementes ca. $0,5-0,7$ $\times 0,2 \mathrm{~mm}$, castanho-avermelhadas, translúcidas, fusiformes a lanceoladas, reticuladas ou estriadas, ápice apiculado.

Material examinado selecionado: Antonina, UHE Parigot de Souza-Cota 800, 26.I.2015, fl., L.F. Bacci 142 (MBM). Balsa Nova, BR-277, paredão próx. pedágio São Luís do Purunã, 2527'55'S, 49³9'10"O, 19.II.2012, fl., E.D. Lozano \& B.K. Canestraro 890 (MBM). Campina Grande do Sul, Serra do Ibitiraquire, próximo ao cume do Itapiroca, $25^{\circ} 14^{\prime} 44^{\prime \prime} \mathrm{S}, 48^{\circ} 50^{\prime} 5^{\prime}{ }^{\prime} \mathrm{O}$, 22.I.2014, fl., E.D. Lozano et al. 2556 (MBM). Campo Largo, próximo ao portal de São Luís do Purunã, 25'28'27''S, 4942'38'O, 4.XII.2013, fl. e fr., E.D. Lozano 2165 (FLOR, HCF, ICN, MBM, NY, RB, SP, UPCB). Candói, Fazenda Capão Redondo, 25'25'24”S, 51'48'11”O, 12.XII.2013, fl., E.D. Lozano \& M.E. Engels 2284 (MBM). Curitiba, Vila Higienópolis, 22.XII.1971, fl., G. Hatschbach 28566 (MBM, UPCB). Carambeí, Rio São João, 2453'59”S, 507'49”O, 18.II.2014, fl., E.D. Lozano \& D.P. Saridakis 2636 (MBM, NY, RB, SP, UPCB). Guarapuava, BR-277, em frente à concessionária da John Deere, $25^{\circ} 22^{\prime} 24^{\prime \prime}$, 51'30'2"O, 11.XII.2013, fl., E.D. Lozano \& M.E. Engels 2265 (FLOR, HCF, ICN, MBM, NY, SP, UPCB). Jaguariaíva, rodovia para Arapoti, próximo à divisa, 17.I.1965, fl., L.B. Smith 14688 (HBR, R). Lapa, RPPN Mata do Uru, 25'48'36"S, 49 40'56"O, 17.XII.2014, f1., E.D. Lozano et al. 2858 (MBM). Laranjeiras do Sul, Rio Reserva, 18.III.1967, fl., $J$. Lindeman 4994 (MBM). Palmeira, Fazenda Santa

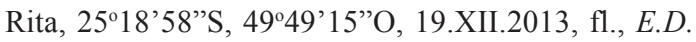
Lozano 2456 (MBM, NY, RB, SP, UPCB). Piraí do Sul, Fazenda Barbante, 24⒉ '26”'S, 49 $58^{\prime} 32^{\prime \prime} \mathrm{O}$, 28.XI.2013, fl., E.D. Lozano \& D.P. Saridakis 2007 (HCF, MBM, NY, SP, UPCB). Piraquara, Mananciais da Serra, 19.IV.2008, fr., A.R. Silva 664 (MBM, HCF). Ponta Grossa, PARNA dos Campos Gerais, Cachoeira São Jorge, 252'4”'S, 50³'20'O, 20.XII.2013, fl., E.D. Lozano \& B. Damasceno 2499 (ICN, MBM, NY, SP, UPCB). Quatro Barras, Rio Taquari, 24.I.1965, fl., $G$. Hatschbach 12338 (MBM). São Jeronimo da Serra, Reserva Indígena São Jeronimo, 27.V.2002, fl., K.L.V.R. Sá $167 a$ (FUEL). São José dos Pinhais, Colônia Santos Andrade, 3.II.1967, fl., G. Hatschbach 15948 (MBM, NY, UPCB). São Mateus do Sul, Vila S'Ana, 8.II.1966, f1., G. Hatschbach 13786 (MBM). Sengés, PR-151, Rio

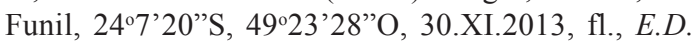
Lozano \& D.P. Saridakis 2100 (MBM). Tibagi, Fazenda Pinheirinho, 243' ' '’S, 50¹7'52'O, 6.VII.2013, fl., E.D. Lozano 1289 (MBM).
Distribuição e hábitat: Xyris tortula é endêmica do Brasil, distribuindo-se nos estados: Bahia, Distrito Federal, Espirito Santo, Goiás, Minas Gerais, Mato Grosso do Sul, Mato Grosso, Paraná, Rio Grande do Sul, Rio de Janeiro, Santa Catarina e São Paulo (Flora do Brasil 2020 em construção). No Paraná, ocorre nos três planaltos e nas montanhas mais baixas da Serra do Mar.

É uma das espécies mais comuns no estado, ocorrendo em ambientes com constante fluxo de água, como valas à beira da estrada e margem de rios. Raramente é encontrada em banhados, mas pode ocorrer neste tipo de ambiente. Nas populações encontradas no Paraná, geralmente não forma touceiras, sendo mais comum encontrar indivíduos solitários.

Fenologia: é encontrada com flores de novembro a março. Foi observada com flores abertas apenas pela manhã.

Notas taxonômicas: por possuir tricomas na base da bainha, lâmina achatada, lígula ausente e brácteas sem mácula, dentre as espécies que ocorrem no Paraná, Xyris tortula pode ser confundida com Xyris asperula e $X$. metallica. Diferencia-se destas por $X$. tortula possuir pedúnculo com a costela glabra, ciliada em $X$. metallica e lâmina e pedúnculo lisos, transverso-rugosos em $X$. asperula.

22. Xyris uninervis Malme, Feddes Repert. Spec. Nov. Regni Veg., 5: 101, 1908.

Fotos disponíveis em Lozano et al. (2016b).

Figs. 6u-z; 7v

Erva solitária ou cespitosa formando pequenas touceiras, perene, base dilatada, mucilagem hialina ausente. Rizoma horizontal com entrenós curtos. Folhas $28,8-56,5 \mathrm{~cm}$ compr., espiraladas, eretas, torcidas; bainha 4,6-12,5 × 0,81-1,15 cm, abruptamente dilatada na base, castanho-fulgente, lisa, margem hialina, tricomas longos na base; lâmina 24-43 × 0,04-0,06 cm, filiforme, verde, lisa, margem glabra, ápice agudo. Lígula presente. Espata 11,2-17,7 × 0,17-0,2 cm, castanho clara, carena ausente, margem glabra, lâmina presente, Pedúnculo 38-88,7 × 0,06-0,12 cm, cilíndrico, verde a castanho, liso, sem costelas. Espiga 6,7-9,8 × 5,1-7,1 mm., elipsoide a globosa; brácteas castanhas, carena ausente, nervura central conspícua, mácula ausente, margem inteira, concolor, glabra; brácteas estéreis ca. 14, oblongas; brácteas florais ca. 18, obovadas. Flores com sépala anterior membranácea, avermelhada; sépalas laterais 5,1-6,8 mm compr., exsertas, estreito-oblongas, inequilatarais, ápice obtuso, 
carena alargada para o ápice, lacerado-fimbriada, porção superior avermelhada; lobo das pétalas 4,4 × 2,4 mm, oblongo a elíptico, margem erosa; estaminódios 1,4-2 mm compr., densamente pilosos por todo ramo; estames 2,3-2,7 mm compr., anteras oblongas; estilete 5,1-7 mm compr., ramos 2,2-2,3 mm compr.; placentação basal. Cápsula ca. $4 \times 1,7 \mathrm{~mm}$, elipsoide. Sementes ca. $0,8 \times 0,3$ $\mathrm{mm}$, castanho-escuras, translúcidas, fusiformes a lanceoladas, estriadas, ápice apiculado.

Material examinado selecionado: Ponta Grossa, Alagados, 13.VII.2007, fr., K. Dalazoana (HUPG 8311). Tibagi, Parque Estadual do Guartelá, 24³4'17'S, 50¹4'59'O, 7.VII.2013, fl., E.D. Lozano 1323 (FLOR, HCF, ICN, MBM, NY, SP, UPCB).

Distribuição e hábitat: era considerada endêmica do estado de São Paulo (Wanderley 2003), sendo um novo registro para o Paraná, onde é encontrada apenas na região dos Campos Gerais e com registros em apenas duas localidades. Ocorre em encostas constantemente úmidas com solo exposto. Fenologia: é encontrada com flores de julho ao início de setembro.

Notas taxonômicas: um dos fatores que pode influenciar na baixa amostragem desta espécie é o fato dela florir no inverno, período este, que geralmente possui uma menor amostragem.

Dentre as espécies que ocorrem no Paraná é similar morfologicamente a Xyris stenophylla, diferindo desta pelas características apresentadas em suas notas taxonômicas.

\section{Agradecimentos}

Agradecemos ao ICMBio e ao IAP, as licenças de coletas nas unidades de conservação; a Klei Sousa, as ilustrações; aos curadores e à equipe dos herbários consultados; aos revisores, a contribuição na formatação do texto; e a todos que participaram durante a elaboração deste trabalho. $\mathrm{O}$ presente trabalho foi realizado com apoio da Coordenação de Aperfeiçoamento de Pessoal de Nível Superior - Brasil (CAPES) - Código de Financiamento 001.

\section{Referências}

Aguiar TH \& Vieira AOS (2011) Florística do Parque Estadual do Cerrado de Jaguariaíva - Paraná: atualização da lista de espécies. In: Carpanezzi OT \& Campos JB (org.). Coletânea de Pesquisas do Parque Estadual de Vila Velha, Cerrado e Guartelá. IAP, Curitiba. Pp. 263-272.

Alvares CA, Stape JL, Sentelhas PC, Gonçalves JLM \& Sparovek G (2013) Köppen's climate classification map for Brazil. Meteorologische Zeitschrift 22: 711-728.
Andrade BO, Kozera C, Curcio GR \& Galvão F (2011) Vascular grassland plants of Tibagi River Spring, Ponta Grossa, Brazil. Check List 7: 257-262.

Bouchenak-Khelladi Y, Muasya AM \& Linder HP (2014) A revised evolutionary history of Poales: origins and diversification. Botanical Journal of the Linnean Society 175: 4-16.

Campbell LM (2005) Contributions towards a monograph of Xyridaceae: a revised nomenclature of Abolboda. Harvard Papers in Botany 10: 137-145.

Cervi AC, von Linsingen L, Hatschbach G \& Ribas OS (2007) A vegetação do Parque Estadual de Vila Velha, município de Ponta Grossa, Paraná, Brasil. Boletim do Museu Botânico Municipal 69: 1-52.

Dalazoana K (2010) Espacialização dos campos nativos na escarpa devoniana do Parque Nacional dos Campos Gerais, PR. Dissertação de Mestrado. Universidade Estadual de Ponta Grossa, Ponta Grossa. 145p.

Dallwitz MJ, Paine TA \& Zurcher EJ (2011) OPEN DELTA Editor: description language for taxonomy. Disponível em $<$ https://code.google.com/p/open-delta/>. Acesso em 9 março 2014.

Falleiros RM, Zenni RD \& Ziller SR (2011) Invasão e manejo de Pinus taeda em campos de altitude do Parque Estadual o Pico Paraná, Paraná, Brasil. Floresta 41: 123-134.

Flora do Brasil (2020 em construção) Xyridaceae In: Flora do Brasil 2020 em construção. Jardim Botânico do Rio de Janeiro. Disponível em $<$ http://floradobrasil. jbrj.gov.br/reflora/floradobrasil/FB252>. Acesso em 22 agosto 2017.

Hatschbach G, von Linsingen L, Cervi AC, Sonehara JC \& Ribas OS (2005) Levantamento Florístico do Cerrado (Savana) Paranaense e Vegetação Associada. Boletim do Museu Botânico Municipal 66: 1-40.

Kozera C, Kuniyoshi YS, Galvão F \& Curcio GR (2009) Composição florística de uma formação pioneira com influência fluvial em Balsa Nova, PR, Brasil. Floresta 39: 309-322.

Kozera C, Kuniyoshi YS, Galvão F \& Curcio GR (2012) Espécies vasculares de uma área de campos naturais do sul do Brasil em diferentes unidades pedológicas e regimes hídricos. Revista Brasileira de Biociências 10: 267-274.

Kral R (1988) The genus Xyris (Xyridaceae) in Venezuela and contiguous northern South America. Annals of the Missouri Botanical Garden 75: 522-722.

Kral R (1998) Xyridaceae. In: Kubitzki K(ed.). The families and genera of vascular plants. Vol. 4. Flowering plants, monocotyledons, Alismatanae and Commelinanae (except Gramineae). Springer Verlag, Berlin. Pp. 461-469.

Kral R \& Wanderley MGL (1988) Ten novelties in Xyris (Xyridaceae) from the Planalto of Brazil. Annals of the Missouri Botanical Garden 75: 352-372.

Kunth CS (1843) Enumeratio Plantarum. Stutgard, J.G. Collae 4: 1-29. 
Linnaeus C (1753) Species Plantarum 1. L. Salvius, Stockholm. 560p.

von Linsingen L, Sonehara JS, Uhlmann A \& Cervi A (2006) Composição florística do Parque Estadual do Cerrado de Jaguariaíva, Paraná, Brasil. Acta Biológica Paranaense 35: 197-232.

Lozano ED (2014) Xyridaceae. In: Kaehler M, Goldenberg R, Evangelista PHL, Ribas OS, VieiraAO \& Hatscbach GG (org.). Plantas Vasculares do Paraná. Universidade Federal do Paraná, Curitiba. Pp. 189.

Lozano ED, Smidt EC \& Wanderley MGL (2016a) A new species of Xyris (Xyridaceae) from Brazil. Phytotaxa 245: 084-088.

Lozano ED, Smidt EC \& Wanderley MGL (2016b) A Família Xyridaceae no estado do Paraná, Brasil. Field Guides - Field Museum, Chicago. Disponível em $<$ https://fieldguides.fieldmuseum.org/sites/default/files/ rapid-color-guides-pdfs/748_brazil-_xyridaceae.pdf $>$. Acesso em 10 agosto 2018.

Maack R (1968) Geografia física do estado do Paraná. Banco do Desenvolvimento do Paraná. UFPR/IBPT, Curitiba. 351p.

Malme GO (1899) Die Xyridaceen Paraguays. Bulletin de L'Herbier Boissier 7: 75-78.

Malme GO (1908) Xyrids austro-americanae novae II. Repertorium specierum novarum regni vegetabilis 5: 101-103.

Malme GO (1913) Xyris L. Untergattung Nematopus (Seubert). Entwurf einer Gliederung. Arkiv för Botanik. 13: $1-103$.

Malme GO (1925) Xyridologische Beiträge. Arkiv För Botanik 19: 1-8.

Martius CFP (1841) Beiblätter zur Flora. Flora oder Botanische Zeitung 24: 1-112.

Miquel FAW (1844) Floram Surinamensem. Linnaea 18: 563-624.

Mocochinski AY \& Scheer MB (2008) Campos de altitude na Serra do Mar paranaense: aspectos florísticos. Floresta 38: 625-640.

Mota NFO, Campbell LM, Viana PL \& Wanderley MGL (2015) Xyridaceae of Viruá National Park, Roraima state, Brazil. Rodriguésia 66: 523-553.

Nilsson AL (1892) Studie über die Xyrideen. Kongliga Svenska vetenskaps-akademiens handlingar 24: 1-72.

Richard LC (1792) Catalagus Plantarum. Actes de la Societe D'Histoire Naturelle Paris 1: 105-114.

Ritter LMO, Ribeiro MC \& Moro RS (2010) Composição florística e fitofisionomia de remanescentes disjuntos de Cerrado nos Campos Gerais, PR, Brasil - limite austral do bioma. Biota Neotropica 10: 379-414.

Roderjan CV, Galvão F, Kuniyoshi YS \& Hatschbach GG (2002) As unidades fitogeográficas do estado do Paraná. Ciência e Ambiente 24: 75-92.

Seubert M (1855) Xyrideae. In: Martius CFP \& Eichler AG (eds.). Flora brasiliensis. Frid. Fleischer, Leipzig. Vol. 3, pars 1, pp. 209-224.
Silva GO \& Wanderley MGL (2013) A família Xyridaceae no município de Mucugê, BA, Brasil. Hoehnea 40: 51-76.

Smith LB \& Downs RJ (1960) Xyridaceae from Brazil - II. Proceedings of the Biological Society of Washington 73: 245-260.

Smith LB \& Downs RJ (1965) Xyridáceas. In: Reitz PR (ed.). Flora Ilustrada Catarinense. Herbário Barbosa Rodrigues, Itajaí. 53p.

Smith LB \& Downs RJ (1966) Xiridáceas novas ou críticas do Brasil. Arquivos de Botânica do estado de São Paulo 4: 25-32.

Smith LB \& Downs RJ (1968) Xyridaceae. In: Hoehne FC \& Teixeira AR (eds.). Flora Brasilica. Fasc. 12. Vol. 9. Instituto de Botânica, São Paulo. Pp. 1-214.

Thiers B [continuamente atualizado] Index Herbariorum: a global directory of public herbaria and associated staff. New York Botanical Garden's Virtual Herbarium. Disponível em $<$ http://sweetgum.nybg.org/science/ $\mathrm{ih} />$. Acesso em 3 fevereiro 2015.

Thunberg CP (1794) Prodromus Plantarum Capensium. Edman, Uppsala. 83p.

Tramujas AP (2000) A vegetação dos campos de altitude na região do Ibitiraquire - Serra do Mar - municípios de Antonina, Morretes e Campina Grande do Sul, Paraná. Dissertação de Mestrado. Universidade Federal do Paraná, Curitiba. 83p.

Wanderley MGL (2003) Xyridaceae. In: Wanderley MGL, Shepherd GJ, Giulietti AM, Melhem TSA, Giulietti AM \& Kirizawa M (eds.). Flora fanerogâmica do estado de São Paulo. Instituto de Botânica, São Paulo. Vol. 3, pp. 333-348.

Wanderley MGL (2010) Cinco novas espécies de Xyris (Xyridaceae) da Serra do Cipó, Minas Gerais, Brasil. Rodriguésia 61: 83-94.

Wanderley MGL (2011) Flora da serra do cipó, Minas Gerais: Xyridaceae. Boletim de Botânica da Universidade de São Paulo 29: 69-134.

Wanderley MGL (2017) Typification of binomials in Xyris section Nematopus (Xyridaceae) published by L.A. Nilsson. PhytoKeys 80: 65-76.

Wanderley MGL, Silva GO, Guedes JS, Valente ASM, Fernandez EP, Monteiro NP \& Borges RAX (2013) Xyridaceae. In: Martinelli G \& Moraes MA (eds.). Livro vermelho da flora do Brasil. Andrea Jakobsson, Instituto de Pesquisas Jardim Botânico do Rio de Janeiro, Rio de Janeiro. Pp. 1027-1036.

Ziller SR (2000) A estepe gramíneo-lenhosa no segundo planalto do Paraná: diagnóstico ambiental com enfoque à contaminação biológica. Tese de Doutorado. Universidade Federal do Paraná, Curitiba. 242p.

Ziller SR \& Galvão F (2002) A degradação da Estepe Gramíneo-Lenhosa no Paraná por contaminação biológica de Pinus elliotti e Pinus taeda. Floresta 32: 41-47. 


\section{Apêndice}

Lista de material examinado separados por coletor, nome e números. Os números em parênteses referem-se às espécies.

Espécies:

1. Xyris asperula Mart.

2. Xyris capensis Thunb.

3. Xyris cervii E.D. Lozano \& Wand.

4. Xyris dissitifolia Kral \& Wand.

5. Xyris dusenii Malme

6. Xyris glandacea L.A.Nilsson

7. Xyris guaranitica Malme

8. Xyris hatschbachii L.B.Sm. \& Downs

9. Xyris hymenachne Mart.

10. Xyris jupicai Rich.

11. Xyris lucida Malme

12. Xyris metallica Klotzsch \& Seub.

13. Xyris neglecta L.A.Nilsson

14. Xyris piraquarae L.B.Sm. \& Downs

15. Xyris regnellii L.A.Nilsson

16. Xyris rigida Kunth

17. Xyris savanensis Miq.

18. Xyris schizachne Mart.

19. Xyris stenophylla L.A.Nilsson

20. Xyris tenella Kunth

21. Xyris tortula Mart.

22. Xyris uninervis Malme

\section{Lista de exsicatas}

Aguiar TH 85 (17), 121 (20). Andrade BO 48 (13), 49 (13), 50 (13), 52 (15), 53 (15), 54 (19), 56 (10), 354 (10). Ariati V 157 (14). Bacci LF 42 (21), 143 (10). Bach A HUPG13124 (21). Barbosa DM 8 (10). Barbosa E 852 (1), 875 (21), 1369 (3), 3469 (19), 3562 (10), 4000 (13), 4078 (10). Barros F 2125 (10). Bergano N FUEL5256 (13). Bini LM 35 (10). Bona C 248 (10), 310 (15). Braga R 8 (10). Britez RM PKDC24742 (10), PKDC25691 (10). Brotto ML 964 (20), (11), 1365 (2), 1446 (10). Bufrem A 34 (21). Buttura 450 (10). Carmo MRB 91 (13), 180 (3), 359 (13), 474 (9), 561 (9), 562 (20), 726 (10), 1026 (17), 1072 (13), HUPG12674 (17), HUPG12675 (10). Castellanos A 21857 (21), 21858 (9), 21859 (17), 21861 (2), 21862 (21), 21863 (13). Caxambu MG 611 (20), 834 (18), 960 (10), 973 (17), 2871 (2). Ceccantini GCT 1470 (10), 1479 (1). Cervi AC 1978 (10), 3423 (10), 4014 (8), 4275 (20), 8116 (8), 8548 (11), 8581 (2), 8584 (18). Cordeiro J 2 (10), 376 (5), 433 (10), 591 (13), 593 (19), 1458 (10), 2146 (5), 4154 (13), 5125 (8). Corsi A HUEM9344 (21). Costa ME HUPG838 (1). Cotarelli VM 387 (18). Cruz JM 76 (10). Czech LR HUPG1688 (10). Dalazoana K HUPG18176 (13), HUPG8311 (22). Davidse G 11251 (10). Dittrich VAO 239 (5). Doim L HUPG16699 (2), HUPG16701 (10). Dombrowski LT 83 (1), 220 (10), 850 (19), 906 (5), 1271 (17), 1386 (1), 2070 (5), 2090 (17), 2101 (5), 2211 (13), 2326 (17), 2329 (1), 2558 (1), 2609 (5), 2982 (18), 4350 (13), 5849 (10), 5894 (10), 6173 (10), 6715 (21), 6718 (19), 9078 (19), 9380 (1), 9830 (5), 9932 (13), 9955 (13), 10430 (10), 11002 (1), 12220 (20), 12223 (8), 12311 (17), 12389 (17), 12712 (17), 12754 (17), 13027 (10), 13188 (10), 14013 (8), 14444 (8), PKDC16041 (10). Dunaiski A 2296 (21). Dusén P 2297 (18), 2299 (17), 2336 (17), 2358 (15), 2573 (18), 2737 (19), 3638 (10), 3735 (10), 3737 (18). Engels ME 502 (10), 2018 (13), 2020 (13), 2507 (17), 2530 (10). Estevan DA 603 (1), 604 (10), (10). Felitto G 11 (21), 193 (11), 437 (13). Ferreira E HCF1016 (10). Ferrucci S 280 (21). Fiaschi P 3585 (10). Forzza RC 7313 (2), 7344 (13). Francisco EM 227 (10). Gatti G 122 (17). Goldemberg R 497 (1). Hansen B 10942 (12). Hatschbach G 828 (8), 1556 (5), 1613 (14), 1922 (10), (17), $2201(10), 3911$ (10), $3912(13), 5120(20), 5365(21), 5375(17), 5585(10), 5586(10), 6469(5), 6583(11), 6849(10), 7470(19), 7480(15), 8364$ (13), 8872 (10), 9562 (1), 9640 (2), 9707 (5), 10853 (13), 12156 (10), 12222 (1), $12260(20), 12338(21), 12412(5), 13051$ (8), 13130 (13), 13206 (13), 13208 (9), 13346 (10), 13485 (13), 13631 (10), 13654 (2), 13722 (10), 13785 (10), $13786(21), 13846$ (10), 13919 (10), 13920 (10), 13999 (20), 14179a (21), 14179b (6), 14203 (9), 14263 (10), 15062 (2), 15069 (13), 15110 (8), 15372 (13), 15418 (2), 15462 (17), 15468 (18), 15472 (15), 15905 (10), 15948 (21), 15954 (10), 15973 (10), 15975 (18), 15977 (17), 15982 (1), 16821 (14), 17233 (17), $17746(13), 17853$ (14), 18706 (10), 18708 (10), 18786 (21), 20752 (4), 21282 (10), 22807 (13), 23052 (5), 23074 (17), 23387 (14), 23404 (4), 25897 (18), 25911 (17), 26322 (4), 26422 (18), 28099 (11), $28216(15), 28304$ (5), 28473 (13), 28566 (21), 29218 (10), 29263 (7), 29792 (10), 30624 (10), $31102(8), 33392(5)$, 33447 (5), 33471 (13), 33579 (13), 33994 (13), 35529 (5), 35633 (18), 35876 (1), 38038 (10), 38040 (21), 39178 (13), 39189 (20), 40237 (21), 40451 (19), 40463 (5), 41581 (10), 41907 (14), 43551 (1), 45784 (10), 47550 (10), 48121 (10), 49784 (18), 50679 (5), 54854 (20), 56166 (10), 76756 (10). Hoehne FC 23452 (20), SP24331 (10). Imaguire N 3193 (10), 3193 (10). Koazicki 30 (10). Koyama T SP184632 (10). Kozera C 2085 (10), 2503 (13), 2566 (1), 2573 (13), 2607 (1), 2673 (10), 2674 (12), 2695 (19), 2731 (13), 2735 (13), 2773 (1), 2816 (12), 2924 (10), 3019 
(21), 3144 (20), 3145 (17). Krapovickas A 23104 (10), 23283 (10), 33593 (10). Krieger PL 11246 (13), 14802 (17). Kummrow R 218 (10), 790 (21), 1213 (10), 1623 (5), 1693 (10), 1738 (21), 1764 (21), 2431 (8), 3253 (10), 3364 (11). Kunyioshi YS 2597 (10), 2598 (2), 4940 (13), 5424 (17), 5538 (17), 5984 (17), 6128 (10). Landrum LR 2513 (21). Lange R 1043 (18). Lima JM 813 (10). Lindeman JC 867 (10), 1124 (10), 4994 (21), 5058 (10). Lozano ED 185 (13), 221 (14), 502 (21), 560 (21), 759 (22), 866 (1), 890 (21), 1052 (2), 1077 (13), 1168 (19), 1183 (13), $1184(20), 1186(17), 1192(10), 1198(20), 1199(13), 1200(20), 1201(21), 1202(10), 1208(19), 1209(21), 1210(21), 1211$ (9), $1212(10), 1215$ (14), $1216(19), 1218$ (13), 1219 (10), 1220 (21), 1222 (10), 1223 (11), 1227 (2), 1230 (10), 1231 (10), 1232 (13), $1233(17), 1234$ (10), 1235 (1), 1236 (13), 1238 (2), 1239 (4), 1243 (21), 1246 (17), 1285 (10), 1286 (9), 1287 (10), 1288 (17), 1289 (21), 1317 (13), 1323 (22), $1486(20), 1534$ (5), 1535 (2), 1575 (5), 1576 (14), 1585 (19), 1610 (5), 1626 (2), 1627 (13), 1628 (19), 1655 (2), 1664 (13), 1697 (13), 1698 (20), 1699 (19), 1709 (21), 1731 (10), 1761 (18), 1767 (12), 1860 (14), 1865 (13), 1883 (18), 1884 (13), 1885 (21), 1886 (8), 1887 (9), $1888(17), 1889(10), 1900(21)$, 1901 (17), 1902 (9), 1903 (8), 1904 (13), 1909 (9), 1910 (20), 1911 (13), 1912 (20), 1913 (9), 1914 (17), 1968 (21), 1969 (8), 1970 (9), 1971 (10), 1972 (20), 1973 (17), 1974 (13), 1992 (20), 1993 (8), 1994 (9), 1995 (17), 1996 (10), 2004 (20), 2005 (17), 2006 (13), 2007 (21), 2011 (20), 2024 (9), 2025 (21), 2026 (20), 2027 (17), 2028 (8), 2058 (13), 2059 (18), 2060 (17), 2061 (10), 2062 (8), 2063 (20), 2078 (21), 2079 (10), 2080 (17), 2100 (21), 2101 (9), 2102 (17), 2103 (10), 2104 (18), 2105 (18), 2106 (9), 2107 (17), 2108 (10), 2123 (13), 2124 (18), 2125 (21), $2126(9), 2127$ (8), 2128 (10), 2129 (17), 2130 (20), 2131 (10), 2132 (21), 2133 (13), 2134 (8), 2135 (13), 2136 (17), 2137 (21), 2138 (19), 2139 (9), 2146 (13), 2147 (19), 2148 (2), 2149 (21), 2150 (9), 2151 (8), 2152 (17), 2157 (13), 2158 (19), 2159 (21), 2165 (21), $2166(10), 2167$ (9), 2168 (1), 2169 (19), 2170 (17), 2171 (2), 2175 (21), 2176 (2), 2177 (13), 2178 (2), 2179 (19), 2180 (13), 2195 (10), 2196 (9), 2197 (21), 2198 (8), 2199 (17), 2229 (15), 2230 (13), 2231 (13), 2241 (21), 2242 (13), 2243 (10), 2244 (16), 2255 (15), 2256 (13), 2262 (13), 2263 (15), 2264 (13), 2265 (21), 2266 (12), 2267 (12), 2268 (18), 2269 (13), 2270 (21), 2283 (12), 2284 (21), 2285 (16), 2286 (18), 2287 (2), 2288 (17), 2289 (10), 2311 (15), 2312 (13), 2316 (10), 2317 (18), 2333 (2), 2334 (15), 2347 (2), 2348 (15), 2349 (13), 2355 (15), $2356(5), 2357$ (8), 2358 (17), 2359 (9), 2360 (13), 2361 (20), 2362 (10), 2385 (19), 2386 (9), 2387 (21), 2388 (2), 2389 (8), 2390 (10), 2391 (17), 2392 (13), 2409 (13), 2447 (8), 2448 (21), 2449 (9), 2450 (17), 2451 (13), 2452 (10), 2453 (19), 2454 (8), 2455 (13), 2456 (21), 2457 (2), 2458 (9), 2459 (17), 2460 (19), 2473 (2), 2474 (19), 2475 (13), 2476 (17), 2477 (20), 2478 (8), 2479 (9), 2480 (10), 2497 (13), 2498 (13), 2499 (21), 2500 (8), 2501 (10), 2502 (6), 2503 (17), 2504 (9), 2505 (19), 2507 (13), 2508 (21), 2509 (10), 2511 (13), 2512 (18), 2513 (19), 2514 (9), 2515 (17), 2516 (3), 2517 (21), 2518 (10), 2519 (10), 2520 (1), 2522 (8), 2523 (13), 2530 (21), 2531 (19), 2532 (10), 2533 (13), 2534 (13), 2535 (17), 2536 (20), 2537 (8), 2538 (1), 2540 (10), 2541 (7), 2542 (10), 2543 (7), 2544 (10), 2545 (10), 2546 (7), 2547 (10), 2548 (7), 2554 (14), 2555 (19), $2556(21), 2557$ (17), 2558 (10), 2618 (19), 2620 (19), 2621 (9), 2622 (10), 2623 (10), 2624 (11), 2625 (21), 2632 (10), 2633 (18), 2634 (6), 2635 (13), $2636(21), 2637(1), 2638(9), 2639(17), 2640$ (6), 2641 (1), 2642 (3), 2643 (10), 2644 (10), 2680 (1), 2681 (17), 2682 (3), 2683 (10), 2712 (19), 2733 (22), 2858 (21), 2859 (17), 2860 (10), 2861 (9), 2903 (9), 2904 (21), 2908 (4), 2917 (5), 2930 (10), 3003 (17), 3004 (17), 3005 (17), 3006 (17), 3007 (17), 3008 (17), 3009 (17), 3010 (17), 3011 (17), 3012 (17), 3013 (17), 3014 (17), 3023 (3), 3256 (10), 3282 (10), 3283 (17), 3314 (11), 3315 (21), 3316 (9). Machado AA HCF2005 (10). Machado LC 12 (10). Marafon CA 194 (10). Mattos A 4432 (9), 4709 (17), 4747 (18), 4332a (13), 4332b (1). Mocochinski AY 136 (11), 233 (4), 234 (19). Moreira EA 35 (13). Moro RS 510 (13), 646 (8), 651 (20), 655 (8), 941 (3), HUPG10453 (17), HUPG10724 (10), HUPG11769 (2), HUPG13437 (10), HUPG13438 (2), HUPG13439 (2), HUPG16866 (1), HUPG17322 (1), HUPG3332 (10). Motta JT 1048 (19). 2089 (20), 2108 (10), 2244 (21), 2325 (17), 2330 (10), 2409 (10), 4169 (13), 4181 (8). Muniz FS 419 (10), 421 (10), 422 (10). Neuhaus S HUPG11318 (8). Nogueira-Souza MKI 166 (1). Pabst G 5901 (17). Parolin M HCF9943 (13). Pauli AC 29 (10). Pereira E 5485 (21), 6075 (17). Poliquesi CB 676 (13). Prado J 400 (10). Reginato M 373 (21). Reinert 76 (10). Reitz R 17455 (13), 17480 (13), 17483 (8), 17501 (20), 17627 (15), 17677 (12), 17873 (13). Ribas OS 82 (10), 207 (13), 209 (20), 1057 (10), 1708(21), 2156 (19), 5843 (10), 8533 (21), 8553 (1). Ristow R 4120 (10). Rocha DC HUPG1705 (17). Roderjan CV 1322 (21), 1356 (14), 1489 (5), 1522 (10), 1538 (4), 1691 (11), MBM310300 (7). Rosa CILF 131 (10). Ruas PM FUEL6035 (20). Sá KLVR 455 (10), 167a (21), 167b (18). Saldanha J 8833 (13), 8833 (21). Santos EM 2161 (17). Santos EP 275 (11), 354 (11), 846 (19), 850 (11). Santos-Silva F 134 (5). Saridakis DP 202 (19), 303 (6), 305 (17), 306 (20), 320 (10), 332 (7), 339 (10), 340 (1), 341 (21), 347 (10), 371 (10), 372 (17), 445 (17), 446 (1), 459 (10), 461 (9), 463 (17), 465 (20), (9), 471 (20), 472 (1), 473 (10). Scheer MB 602 (14), 604 (19). Schwacke 2485 (20), 2491 (19), 2492 (20). Schwartsburd PB 1023 (10). Selusniaki M 2447 (1). Silva AR 664 (21). Silva JM 258 (5), 422 (13), 565 (10), 3271 (19), 6331 (1). Silva SCA 122 (10). Silva SM 1647 (13), UPCB32113 (10). Silva WS 42 (10), 385 (10). Silveira M 76 (21), 90 (13). Siqueira EL 309 (10), 422 (20). Smith LB 9586 (10), (15), 9590 (18), 14541 (13), 14607 (1), 14688 (21), 14783 (17), 14785 (20), 14805 (1), 14881 (13), 14883 (12), (21). Souza WS 42 (10), 24741 (10), 25094 (10). Stawiarski V R76564 (10). Stellfeld C 1607 (10). Takahashi EK 16 (21). Takeda IJM 508 (3), (13), HUPG10869 (10). Tardivo RC HUPG11181 (21). Tesmann G 299 (13), 327 (17), 2611 (10), 2773 (2), 2941 (10), 2990 (17), 3612 (17), 3655 (10), 3743 (5). Tramujas AP 244 (19). Venancio EJ FUEL8476 (10). Vieira MEM 15 (20). Von-Linsingen L 466 (20). Wanderley MGL 3002 (19). Zangano W FUEL6854 (7). Ziller SR 280 (5), 342 (10), 1568 (20), (1), 1738 (19), 1740 (10), 1956 (13). 